\title{
SO2 emissions, plume heights and magmatic processes inferred from satellite data: The 2015 Calbuco eruptions
}

DOI:

10.1016/j.jvolgeores.2018.08.001

\section{Document Version}

Accepted author manuscript

Link to publication record in Manchester Research Explorer

\section{Citation for published version (APA):}

Pardini, F., Burton, M., Arzilli, F., La Spina, G., \& Polacci, M. (2018). SO emissions, plume heights and magmatic processes inferred from satellite data: The 2015 Calbuco eruptions. Journal of Volcanology and Geothermal Research. https://doi.org/10.1016/j.jvolgeores.2018.08.001

\section{Published in:}

Journal of Volcanology and Geothermal Research

\section{Citing this paper}

Please note that where the full-text provided on Manchester Research Explorer is the Author Accepted Manuscript or Proof version this may differ from the final Published version. If citing, it is advised that you check and use the publisher's definitive version.

\section{General rights}

Copyright and moral rights for the publications made accessible in the Research Explorer are retained by the authors and/or other copyright owners and it is a condition of accessing publications that users recognise and abide by the legal requirements associated with these rights.

\section{Takedown policy}

If you believe that this document breaches copyright please refer to the University of Manchester's Takedown Procedures [http://man.ac.uk/04Y6Bo] or contact uml.scholarlycommunications@manchester.ac.uk providing relevant details, so we can investigate your claim.

\section{OPEN ACCESS}


$1 \mathrm{SO}_{2}$ emissions, plume heights and magmatic processes inferred from satellite data:

2 the 2015 Calbuco eruptions

3 Federica Pardini ${ }^{1}$, Mike Burton ${ }^{1}$, Fabio Arzilli ${ }^{1}$, Giuseppe La Spina ${ }^{1}$, Margherita Polacci ${ }^{1}$

$4 \quad{ }^{1}$ School of Earth and Environmental Science, University of Manchester, Manchester, M13 9PL, 5 UK

6 Corresponding author: Federica Pardini (federica.pardini@manchester.ac.uk)

7 Key points:

8
- Satellite data from GOME-2 and numerical modelling are used to investigate $\mathrm{SO}_{2}$ emissions during the 2015 Calbuco eruptions

- Numerically retrieved quantities ( $\mathrm{SO}_{2}$ loading, plume heights and mass eruption rates) are used to investigate magmatic processes such as excess degassing

- Petrological analyses on Calbuco tephra samples validate the hypothesis inferred from space

\section{- Keywords}

$\mathrm{SO}_{2}$ emissions; numerical modelling; excess degassing 


\section{Abstract}

Quantifying time-series of sulfur dioxide $\left(\mathrm{SO}_{2}\right)$ emissions during explosive eruptions provides insight into volcanic processes, assists in volcanic hazard mitigation, and permits quantification of the climatic impact of major eruptions. While volcanic $\mathrm{SO}_{2}$ is routinely detected from space during eruptions, the retrieval of plume injection height and $\mathrm{SO}_{2}$ flux time-series remains challenging. Here we present a new numerical method based on forward- and backwardtrajectory analysis which enable such time-series to be determined.

Using this method applied to GOME-2 satellite imagery we investigate the $\mathrm{SO}_{2}$ emissions from two sub-Plinian eruptions of Calbuco, Chile, produced in April 2015. Our results show a mean injection height of $15 \mathrm{~km}$ for the two eruptions, with overshooting tops reaching $20 \mathrm{~km}$. We calculate a total of $0.295 \pm 0.045 \mathrm{Tg}$ of $\mathrm{SO}_{2}$ emitted, with $0.140 \pm 0.033 \mathrm{Tg}$ produced by the first eruption and $0.155 \pm 0.031 \mathrm{Tg}$ by the second one. Using standard models we convert plume heights to mass eruption rates (MER). Comparing gas flux and MER we discover quite different volcanic processes driving the two eruptions, with the first eruption producing an $\mathrm{SO}_{2}$ flux three times higher than the second one, while they both had similar MERs. We propose that this difference reflects different exsolved volatile contents before the onset of the two eruptions, with the first eruption richer in pre-exsolved gas than the second one. This hypothesis is supported by melt inclusion measurements of sulfur concentrations in plagioclase phenocrysts and groundmass glass of tephra samples through electron microprobe analysis. Combining the satellite and petrological analysis, we propose that the overpressure caused by the pre-exsolved volatile phase (not only $\mathrm{SO}_{2}$, but also probably $\mathrm{H}_{2} \mathrm{O}$ and $\mathrm{CO}_{2}$ ) may have triggered the eruption.

These results demonstrate that our new methodology produces constraints on $\mathrm{SO}_{2}$ flux and plume height time-series permitting new insights into sub-surface processes using satellite $\mathrm{SO}_{2}$ data. 


\section{Introduction}

Understanding the manner and the abundance of sulfur degassing from active volcanoes during explosive eruptions is one key to unravelling eruptive dynamics (Oppenheimer et al., 2011, Wallace and Edmonds, 2011). At a volcanic vent, sulfur gases contribute 2-35 vol\% of total gas emissions, with $\mathrm{SO}_{2}$ and $\mathrm{H}_{2} \mathrm{~S}$ the dominant sulfur-bearing components, ranging between 1-25 vol\% and 1-10 vol\% respectively (Textor et al., 2004). Satellite-based instruments operating in the ultraviolet and infrared have detected and quantified volcanic sulfur gases in the atmosphere since 1978 (Carn et al., 2016). Nowadays, this is routinely done for $\mathrm{SO}_{2}$ (Brenot et al., 2014), while few $\mathrm{H}_{2} \mathrm{~S}$ satellite retrievals have been performed so far (Clarisse et al., 2011). Satellitebased monitoring of volcanic $\mathrm{SO}_{2}$ emissions is of value for poorly monitored volcanoes, which make up almost $95 \%$ of all volcanoes, but are also useful when well-monitored volcanoes erupt explosively, as local detection system can be saturated or blinded by ash.

Satellite images of volcanic $\mathrm{SO}_{2}$ plumes contain a lot of information that can be extracted with the appropriate data analysis approach (McCormick et al., 2014; Hayer et al., 2016). The most immediate information is typically vertical column amounts of $\mathrm{SO}_{2}$, which can be readily used to determine a total $\mathrm{SO}_{2}$ mass loading, and this is the most frequently used type of data provided in the literature. We highlight, however, that retrieved $\mathrm{SO}_{2}$ column amounts are sensitive to plume height, which is not always well-constrained. Valuable time-series information on $\mathrm{SO}_{2}$ injection height and $\mathrm{SO}_{2}$ flux time-series are theoretically available, and these allow subtle observations and deductions on the volcanic processes driving eruptions, including magma degassing (Carn et al., 2008; Carn and Prata 2010; Campion 2014) and the role of pre-eruptive gas accumulation (Westrich and Gerlach, 1992). While a lot of work has been done on $\mathrm{SO}_{2}$ satellite retrievals, a comprehensive, general methodology able to fully characterize both $\mathrm{SO}_{2}$ flux and plume height 
time-series has not been successfully created to date. This is mainly due to the difficulty in retrieving $\mathrm{SO}_{2}$ vertical profiles for individual $\mathrm{SO}_{2}$ column amount pixels in an image. All satellite-based $\mathrm{SO}_{2}$ column amount calculations are dependent on both the measured $\mathrm{SO}_{2}$ optical depth and the plume height, and so quantification of $\mathrm{SO}_{2}$ amounts requires an accurate determination of plume height pixel by pixel in an image. Plume heights have been retrieved using infrared and ultraviolet spectra (Yang et al., 2010; Nowlan et al., 2011; Rix et al., 2012; Carboni et al., 2012; Clarisse et al., 2014; Carboni et al., 2016; Grainger et al., 2016) and from numerical models applied to satellite images (Hughes et al., 2012; Moxnes et al., 2014; Heng et al., 2016; Pardini et al., 2017).

$\mathrm{SO}_{2}$ flux time-series can be calculated from satellite imagery using a variety of methods (a review is presented in Theys et al., (2013). Four methodologies have been applied: the box method (Lopez et al., 2013), the traverse method (Merucci et al., 2011), the delta method (Krueger et al., 1996) and inverse modelling (Eckhardt et al., 2008, Boichu et al., 2013). Depending on the input parameters (plume age at the measurement time, satellite sensor spatial resolution, number of satellite acquisitions in a day, etc...) and expected outcomes (flux timeseries, plume height time-series), each method has strengths and weaknesses. The box method is suitable for a first flux evaluation, but it needs constant wind speed and direction together with an a priori estimation of plume height. The traverse method has been used to compare fluxes retrieved from satellite-based instruments with those from ground based measurements. This technique allows an almost real time estimate of $\mathrm{SO}_{2}$ flux, but it needs constant wind direction and plume height as input data. The delta method is independent from wind speed and it produces an estimate of the $\mathrm{SO}_{2}$ lifetime, however multiple satellite overpasses are needed. Finally, the inverse modelling allows us to compute fluxes at high temporal resolution even for 
plume presenting a complex vertical profile. The main drawback of this technique is the computational time.

In this work we present a trajectory model approach, which we call PlumeTraj, and use it to investigate $\mathrm{SO}_{2}$ emissions during explosive eruptions with the aim of exhaustively examining the information which can be obtained from satellite imagery. With PlumeTraj we determine both the plume height for each $\mathrm{SO}_{2}$ pixel in the satellite image and the time at which the $\mathrm{SO}_{2}$ in each pixel was injected into the atmosphere from the eruption column. PlumeTraj integrates the Hybrid Single-Particle Lagrangian Integrated Trajectory model (HYSPLIT) (Stein at al., 2015) with custom-built Python routines to create a semi-automated numerical procedure from which injection height and flux time-series are quantified with relatively low computational costs (12 hours on a 48 node cluster).

PlumeTraj allows us to study both explosive and effusive eruptions, and, for each case study, specific input parameters (such as volcanic location, type of eruption, eruption time) can be set by the user. Our technique requires satellite and wind field datasets, which can be derived from a variety of sources. Indeed, many satellite sensors can detect volcanic $\mathrm{SO}_{2}$ atmospheric abundance (Carn et al., 2016), and, theoretically, each satellite dataset can be used as input for the model. The same can be done for the wind field data, which, however, must be written in a format that HYSPLIT can read. The main advantage is the possibility to retrieve both $\mathrm{SO}_{2}$ flux and plume height. Moreover, mass eruption rates and masses of erupted solid material can be derived from the plume height time-series by applying the well-known relationship between plume height and mass eruption rate (Morton et al., 1956). However, we must consider uncertainties and errors due the satellite retrievals of atmospheric $\mathrm{SO}_{2}$ and the numerical analysis of these data. 
110 We applied our numerical method to GOME-2 satellite images of $\mathrm{SO}_{2}$ plumes emitted by the two 111 recent sub-Plinian eruptions occurred at Calbuco volcano, Chile, in April 2015. The eruptions

112 have been classified as VEI 4 (Romero et al., 2016) and led to ozone depletion in Antarctica

113 (Solomon et al., 2016, Ivy et al., 2017).

114 Our retrieved $\mathrm{SO}_{2}$ flux time-series and masses of erupted material reveal differences between the

115 two eruptions and allow us to infer the presence of a more abundant pre-exsolved gas phase for

116 the first event. To validate and quantify the amount of excess $\mathrm{SO}_{2}$, we perform microprobe

117 analysis of melt inclusions in plagioclase phenocrysts and ground mass of erupted products. This

118 allows us to compare our numerical results with the $\mathrm{SO}_{2}$ loading derived from the "Petrological

119 Method" (Devine et al., 1984), which uses information on the mass loading of each eruption and

120 the volatile loss inferred from the difference in sulfur concentration between melt inclusions and 121 groundmass.

122 The petrological analysis confirms the scenario inferred from space highlighting that the 123 difference between the two eruptions is due to the presence of a higher amount of pre-exsolved $124 \mathrm{SO}_{2}$ for the first event in compare with the second one.

\section{2. Case study: the 22-23 April 2015 Calbuco eruptions}

126 On the evening of 22 April 2015, Calbuco volcano started a new cycle of eruptive activity after

12754 years of quiescence. Calbuco $\left(41.33^{\circ} \mathrm{S}, 72.61^{\circ} \mathrm{W}\right)$ is an active stratovolcano located in the 128 southern region of the Southern Volcanic Zone of the Andes, Chile. It has been volcanically

129 active since the Late Pleistocene to the present, with the formation of 4 principle deposits. The 130 last deposit has a "dome-cone" structure resulting from a series of recent major eruptions which 131 occurred in 1912, 1961, 1971 and 1983-94 (Lopez-Escobar et al., 1992). The new eruptive cycle

132 started on 22 April 2015 and lasted 9 days, until 30 April 2015. An initial sub-Plinian eruption 
133 took place on the evening of 22 April (hereafter Eruption 1), and a second eruption occurred a

134 few hours later in the morning of 23 April (hereafter Eruption 2).

135 Eruption 1 started suddenly at 20:54 UT. A volcanic column more than $15 \mathrm{~km}$ height rose from 136 the main crater and tephra was dispersed in an East-Northeast direction. The overall duration of 137 the event was $1.5 \mathrm{~h}$. After Eruption 1 stopped, moderate seismic events in the form of volcanic 138 tremor were recorded from 00:55 UT. At 04:00 UT, a new eruptive event (Eruption 2) occurred. 139 The eruptive column reached more than $15 \mathrm{~km}$ in altitude and tephra was dispersed in a North, 140 Northeast and East direction. At 10:30 UT the eruption was declared over (SERNAGEOMIN, $1412015 a, 2015 b, 2015 c)$.

142 The eruptions are classified as VEI 4 (Romero et al., 2016) and they produced columns reaching 143 the stratosphere. The stratospheric injection by the volcanic cloud together with the latitude of 144 Calbuco, produced an impact on ozone recovery in Antarctica causing an increase in hole size of 1454.4 million $\mathrm{km}^{2}$ (Solomon et al., 2106; Ivy et al., 2017). Moreover, extensive damage was caused 146 to the Chilean economy, with agricultural and industrial resources close to Calbuco damaged by 147 ash fall, and air traffic over Chile and Argentina disrupted for some hours (Romero et al., 2016). 148 Considering both the tephra fall and PDC deposits, the deposit volume estimated by Castruccio 149 et al., (2016) is $0.38 \mathrm{~km}^{3}$ assuming a deposit density of $1000 \mathrm{~kg} \mathrm{~m}^{-3}\left(0.15 \mathrm{~km}^{3}\right.$ dense rock 150 equivalent DRE), while Romero et al., (2016) report a tephra fall deposit volume of $0.28 \mathrm{~km}^{3}$ 151 considering a deposit density of $997.3 \mathrm{~kg} \mathrm{~m}^{-3}\left(0.11-0.13 \mathrm{~km}^{3} \mathrm{DRE}\right)$. These values are both within 152 the $0.56 \pm 0.28 \mathrm{~km}^{3}$ volume calculated by Van Eaton et al., (2016), which presents a DRE of 153 $0.18 \pm 0.09 \mathrm{~km}^{3}$ assuming a magma density of $2500 \mathrm{~kg} \mathrm{~m}^{-3}$. 


\section{PlumeTraj: Trajectory-based modelling of volcanic plume height and $\mathrm{SO}_{2}$ flux}

155 PlumeTraj is a development of an approach presented by Pardini et al., (2017). This new

156 approach uses a two-step procedure based on a combination of forward and backward

157 trajectories in order to better constrain plume height and thus $\mathrm{SO}_{2}$ flux. We also modified the

158 post-processing phase, changing the selection criteria for acceptable trajectories and adding an

$159 \mathrm{SO}_{2}$ flux calculation. Due to the general implementation of PlumeTraj, it can be easily applied to

160 different volcanic systems to investigate $\mathrm{SO}_{2}$ emissions during eruptive episodes or produced by

161 quiescent degassing, using either single or multiple satellite images.

162 To run PlumeTraj we need one or more satellite images of a volcanic $\mathrm{SO}_{2}$ plume and their

163 associated numerical wind fields. For each pixel in which $\mathrm{SO}_{2}$ is detected, PlumeTraj calculates

164 three quantities. The first quantity, $h$, is the height at which the $\mathrm{SO}_{2}$ is located at satellite

165 measurement time instant (hereafter plume height). The second one, $h_{v e n t}$, is the height above

166 volcanic vent at which $\mathrm{SO}_{2}$ reaches the neutral buoyancy height and the prevailing atmospheric

167 wind starts to disperse the gas into the atmosphere (hereafter injection height). The last one,

$168 t_{\text {vent }}$, is the time when the $\mathrm{SO}_{2}$ reaches the injection height (hereafter injection time). Knowing

169 these three quantities and $\mathrm{SO}_{2}$ column amount from satellite images, we can calculate the $\mathrm{SO}_{2}$

170 mass loading of the plume and $\mathrm{SO}_{2}$ flux time-series as it is enters the atmosphere from the

171 eruption column.

172 Plume parameters are computed by PlumeTraj by calculating trajectories backwards and,

173 potentially, forwards in time. The trajectory calculation is performed by using HYSPLIT (Stein

174 et al., 2015) with custom-designed routines written in the Python Programming Language.

175 Below we describe the PlumeTraj procedure using three satellite images capturing a same plume 
176 at different times. Forward and backward trajectories are run from the pixels of the satellite

177 image for which heights and fluxes are computed.

178 As reported in Figure 1, the magenta pixels represent the plume as seen at day $k$, whilst the blue 179 and yellow pixels are the same plume at days $k+1$ and $k+2$ respectively. For each pixel $j$ of 180 the day $k$ image and for each potential plume height $h_{j}(i)$ in a given range, we calculate forward 181 trajectories $\operatorname{traj}_{j}^{f}(i)$, up to the time of acquisition of the day $k+2$ image. In this example, from 182 pixel $j$ we run four forward trajectories initialized at four different heights $\left(\operatorname{traj}_{j}^{f}(1), \operatorname{traj}_{j}^{f}(2)\right.$, $183 \operatorname{traj}_{j}^{f}(3)$ and $\operatorname{traj}_{j}^{f}(4)$ in Figure 1). Among these trajectories, only those intersecting with the 184 advected/dispersed plume at days $k+1$ and $k+2$ are considered (for example, in Figure 1 only $185 \operatorname{traj}_{j}^{f}(1)$ and $\operatorname{traj}_{j}^{f}(2)$ are acceptable). Then, starting only from $h_{j}(i)$ of each acceptable 186 forward trajectory, we calculate backward trajectories $\left(\operatorname{traj}_{j}^{b}(1), \operatorname{traj}_{j}^{b}(2)\right.$ in Figure 1). We then 187 select as acceptable trajectories only those approaching the volcanic vent location within the 188 umbrella cloud distance and within the time interval of the eruption (for example, in Figure 1 189 only $\operatorname{traj}_{j}^{b}(1)$. is acceptable). We adopt this two-step trajectory analysis to better constrain the 190 height of the plume and show in supplementary materials additional simulations performed with 191 different wind-fields. 


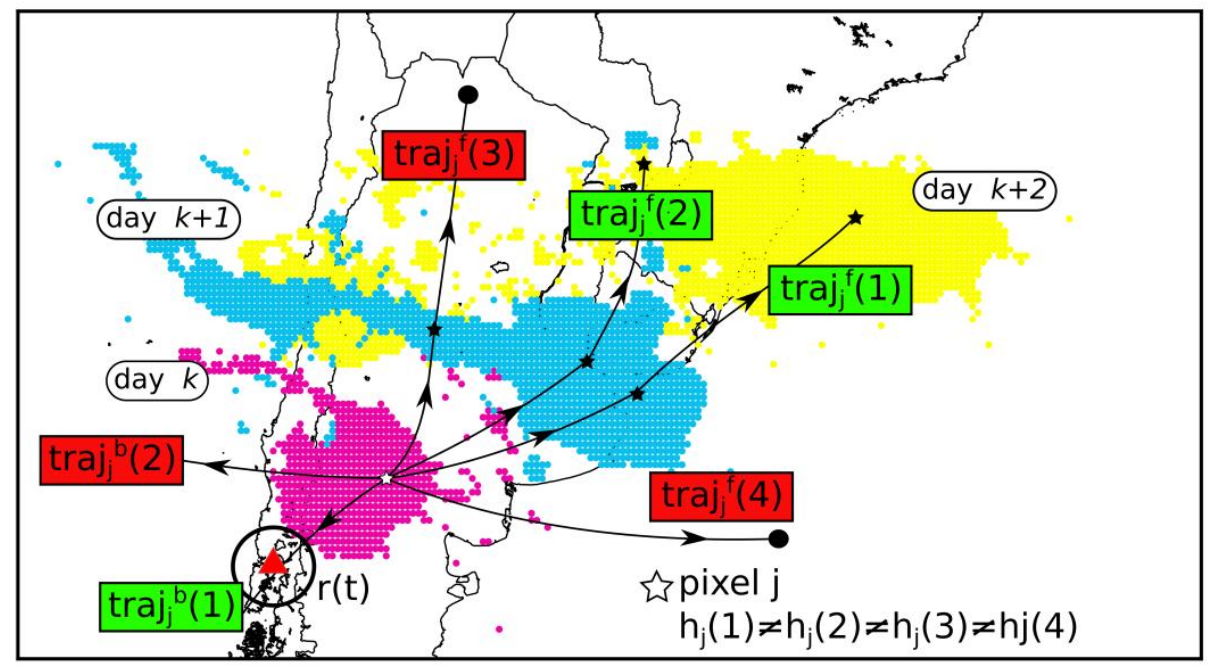

192

193

194

Figure 1 Schematic representation of PlumeTraj numerical procedure. Magenta pixels are those associated with the day $k$ satellite image, while blue and yellow pixels are those from the $d a y k+1$ and $k+2$ images. From pixel $j$ (white star), trajectories $\operatorname{traj}_{j}{ }^{f}(1), \operatorname{traj}_{j}{ }_{j}^{f}(2), \operatorname{traj}_{j}{ }_{j}^{f}(3)$ and $\operatorname{traj}_{j}{ }^{f}(4)$ are run forward from different staring altitudes $\left(h_{j}(1), h_{j}(2)\right.$, $\mathrm{h}_{\mathrm{j}}(3)$ and $\left.\mathrm{h}_{\mathrm{j}}(4)\right)$. While $\operatorname{traj}_{\mathrm{j}}{ }^{\mathrm{f}}(1)$ and $\operatorname{traj}_{\mathrm{j}}^{\mathrm{f}}(2)$ are consistent with the position of the plume at day $k+1$ and day $k+2$, $\operatorname{traj}_{j}{ }^{f}(3)$ and traj ${ }_{j}^{f}(4)$ are not, thus they are neglected. Starting again from pixel $j, \operatorname{traj}_{j}{ }_{j}^{b}(1)$ and traj $j_{j}^{b}(2)$ are initialized from altitudes $h_{j}(1)$ and $h_{j}(2)$ and are run backward in time. Only traj ${ }_{j}^{b}(1)$ is acceptable since it approaches the volcanic vent position at a distance less than $r(t)$.

An acceptable back trajectory is one which lies within the radius of the umbrella cloud, $r(t)$, during the eruption. Following Woods and Kienle, (1994), the radius of an umbrella cloud growing with time at the neutral buoyancy height can be expressed as:

$r(t)=\left(\frac{3 \lambda}{2 \pi} N \cdot V\right)^{\frac{1}{3}} t^{\frac{2}{3}}$

where $\lambda$ is an empirical constant, $N$ is the buoyancy frequency of the atmosphere and $V$ is the volumetric flow rate at buoyancy height. We set $\lambda$ equal to 0.8 and $N$ equal to $0.017 \mathrm{~s}^{-1}$ for stratospheric strong plumes (Sparks et al., 1997). To evaluate the expansion of the umbrella 
209 radius we set the mass eruption rate $(M E R)$ as input data. $M E R$ and $V$ are related through the

210 following relationship (Morton et al., 1956):

$211 \quad M E R \approx\left(\frac{V N^{5 / 8}}{C \sqrt{k_{e}}}\right)^{\frac{4}{3}}$

212 where $k_{e}$ is an entrainment coefficient equal to 0.1 and $C$ is a proportionality constant equal to $213 \quad 1 \cdot 10^{4} \mathrm{~m}^{3} \mathrm{~kg}^{-3 / 4} \mathrm{~s}^{-7 / 8}$.

214 Using the two step PlumeTraj approach, for each pixel $j$ forming the day $k$ plume, and for each 215 acceptable backward trajectory $\operatorname{traj}_{j}^{b}(i)$ starting from the pixel $j$, we extract the three plume 216 parameters $h_{j}(i), h_{j_{v e n t}}(i)$ and $t_{j_{v e n t}}(i)$. The height $h_{j}(i)$ is the altitude of the starting point of 217 the backward trajectory $\operatorname{traj}_{j}^{b}(i)$ of the pixel $j$. Instead, $h_{j_{v e n t}}(i)$ and $t_{j_{v e n t}}(i)$ are respectively 218 the height and the time at which each acceptable backward trajectory $\operatorname{traj}_{j}^{b}(i)$ approaches the 219 vent. From the plume parameters calculated by our numerical method, we compute, for each 220 pixel $j$, the mean values $\left(\bar{h}_{j}, \bar{h}_{j_{v e n t}}\right.$ and $\left.\bar{t}_{j_{v e n t}}\right)$ and standard deviations $\left(\sigma_{j_{h}}, \sigma_{j_{h_{v e n t}}}\right.$ and $\left.\sigma_{j_{t_{v e n t}}}\right)$ as:

$221 \quad \bar{h}=\sum_{i=1}^{N} \frac{h_{j}(i)}{N}$,

$222 \bar{h}_{j_{v e n t}}=\sum_{i=1}^{N} \frac{h_{j_{v e n t}}(i)}{N}$,

$223 \bar{t}_{j_{v e n t}}=\sum_{i=1}^{N} \frac{t_{j_{v e n t}(i)}}{N}$,

$224 \quad \sigma_{j_{h}}=\sqrt{\sum_{i=1}^{N} \frac{\left(h_{j}(i)-\bar{h}\right)^{2}}{N}}$,

$225 \quad \sigma_{j_{h_{\text {vent }}}}=\sqrt{\sum_{i=1}^{N} \frac{\left(h_{j_{\text {vent }}}(i)-\bar{h}_{j_{\text {vent }}}\right)^{2}}{N}}$,

226

$\sigma_{j_{t_{\text {vent }}}}=\sqrt{\sum_{i=1}^{N} \frac{\left(t_{j_{\text {vent }}}(i)-\bar{t}_{j_{\text {vent }}}\right)^{2}}{N}}$, 
where $N$ is the number of backward trajectories $\operatorname{traj}_{j}^{b}(i)$ that approach the vent, $h_{j}(i)$ is the altitude from which trajectories are initialized, while $t_{j_{v e n t}}(i)$ and $h_{j_{\text {vent }}}(i)$ are the time instant and the altitude of approach to the umbrella cloud.

Using these data, we compute the $\mathrm{SO}_{2}$ loading in the volcanic plume and the mass of the tephra fall deposit. Finally, by associating pixels injection times $\left(t_{j_{v e n t}}\right)$ with their $\mathrm{SO}_{2}$ mass loading, which is calculated from the satellite $\mathrm{SO}_{2}$ column amount, we calculate $\mathrm{SO}_{2}$ flux time-series.

Depending on the input images, different combinations between forward and backward trajectories are possible. For example, if the day $k+1$ image of Figure 1 is used as starting image of the simulation, backward trajectories only can be run using the day $k$ image as a target. In the present work we show the results of two PlumeTraj simulations. Both simulations are performed to retrieve $\mathrm{SO}_{2}$ injection height and flux time-series for the 2015 Calbuco eruptive event. The difference between the two simulations is the satellite image used as input data for the trajectories calculations.

\subsection{Application of PlumeTraj to the Calbuco 2015 Eruptions}

To investigate $\mathrm{SO}_{2}$ plumes emitted during the Calbuco 2015 eruptions we use satellite data from the GOME-2 sensor (Rix et al., 2008). GOME-2 is an ultraviolet spectrometer (290-790 nm) aboard the polar-orbiting satellites MetOp-A (launched in 2006) and MetOp-B (launched in 2012) taking global measurements of atmospheric composition on daily basis. The two satellites operate in tandem with a temporal shift between acquisitions of 48 minutes and provide nadirview scans with ground pixel size resolution equal to 40x40 km (swath of $960 \mathrm{~km}$ ) in case of MetOp-A and 80x40 km (swath of $1920 \mathrm{~km}$ ) in case of MetOp-B. Despite GOME-2 has a lower spatial resolution compare to the Ozone Monitoring Instrument (OMI), we used data from 
GOME-2 since the OMI dataset covering the Calbuco eruptions is affected by the so called rowanomalies and thus the $\mathrm{SO}_{2}$ plume is not fully seen by OMI. For GOME-2 retrievals, the Differential Optical Absorption Spectroscopy (DOAS) (Platt and Stutz, 2008) technique is applied to retrieve $\mathrm{SO}_{2}$ vertical column amount by measuring the portion of the sunlight backscattered in the atmosphere. The overall error in $\mathrm{SO}_{2}$ vertical column estimates is in the range $20-70 \%$ (Rix et al., 2012). This range of uncertainty accounts for both random and systematic errors. Random errors are mainly due to instrument noise and they are typically of 520\%. The main contribution to systematic errors comes from the difficulty in assessing the plume height at measurement time and it is estimated to be in the range $10-60 \%$ (Rix et al., 2012). Plume height is a central parameter when converting $\mathrm{SO}_{2}$ slant column density (i.e. the gas concentration along the entire light path) into vertical column density (i.e. the gas concentration right above the satellite footprint). When using an $\mathrm{SO}_{2}$ retrieval made assuming the 261 plume located at a certain height, errors up to $50 \%$ on vertical column amount can arise if the 262 actual plume height is not the one used for the $\mathrm{SO}_{2}$ retrieval. To deal with the missing information on plume height at measurement time, for GOME-2 retrievals, three different $\mathrm{SO}_{2}$ estimates are provided for three hypothetical plume altitudes equal to $2.5 \mathrm{~km}, 6 \mathrm{~km}, 15 \mathrm{~km}$. If we use the $2.5 \mathrm{~km}$ retrieval, this means that the maximum accuracy in $\mathrm{SO}_{2}$ estimation is achieved if the actual plume is located at $2.5 \mathrm{~km}$. In case of different plume height (higher than $2.5 \mathrm{~km}$ ), $\mathrm{SO}_{2}$ column amount for a single pixel can be overestimated up to 70-80\% (Carn et al., 2013). On the contrary, when using the 6 and $15 \mathrm{~km}$ retrievals for a plume which is located at lower heights, 269 the $\mathrm{SO}_{2}$ column amount is underestimated and thus information on plume spatial distribution can 270 be lost. 
271 The first GOME-2 image of the Calbuco $\mathrm{SO}_{2}$ plume was collected at $\sim 13: 00$ on 23 April 2015, 272 after the end of the two eruptive events. Then, plume advection/dispersion paths can be followed 273 for about one month until they are diluted under the satellite detection limit (GOME-2 images 274 can be displayed and datasets downloaded from the Support to Aviation Control Service (SACS) 275 website http://sacs.aeronomie.be/). Due to GOME-2 MetOpA and B different pixel resolution, 276 the original images are re-gridded into a new one presenting a spatial resolution of 30x30 km. 277 For each day we use data from GOME-2 MetOpA, MetOpB or from a combination of the two 278 sensors depending on the possibility to reconstruct the whole $\mathrm{SO}_{2}$ cloud.

279 In Figure 2, we report the atmospheric $\mathrm{SO}_{2}$ loading in Dobson Unit $\left(1 \mathrm{DU}=2.7 \cdot 10^{16}\right.$ molecules $280 \mathrm{~cm}^{-2}$ ) retrieved assuming the plume located at $2.5 \mathrm{~km}, 6 \mathrm{~km}$ and $15 \mathrm{~km}$ on the 23,24 and 25 281 April 2015. To isolate volcanic plumes from background noise, we select pixels with a vertical 282 column higher than a certain threshold calculated applied the Normalized Cloud-mass technique 283 presented in Carn et al., (2008). 

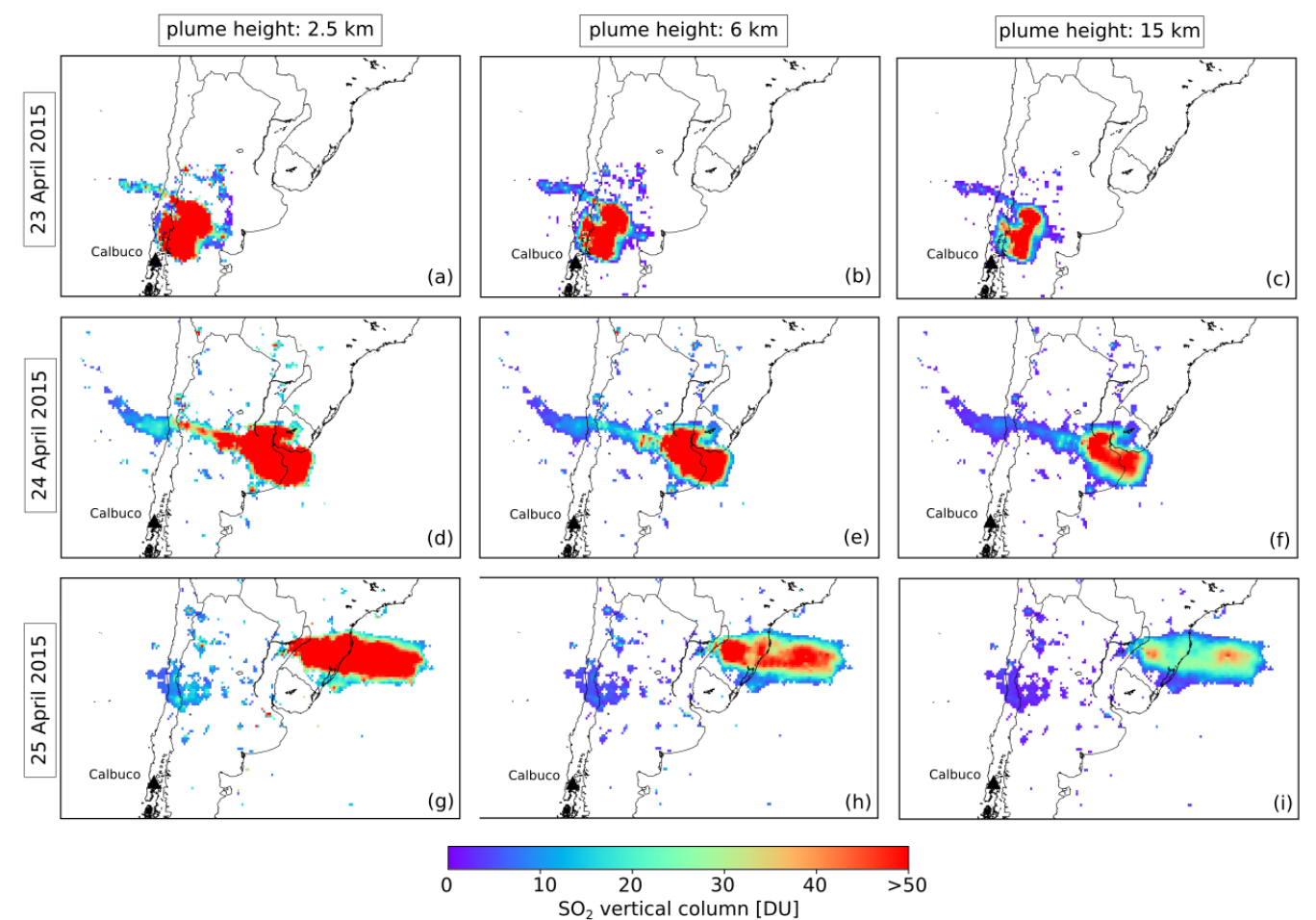

Figure 2 Upper row: Calbuco $\mathrm{SO}_{2}$ plume as seen by GOME-2 on 23 April 2015. The three panels show the $\mathrm{SO}_{2}$ vertical column retrieved assuming a plume altitude of $2.5 \mathrm{~km}(\mathrm{a}), 6 \mathrm{~km}$ (b) and $15 \mathrm{~km}$ (c). In order to isolate the plume from the background noise, thresholds equal to 3.6 DU, 1.95 DU and 0.8 DU have been computed for the 2.5 km, $6 \mathrm{~km}$ and $15 \mathrm{~km}$ images respectively. Middle row: Calbuco $\mathrm{SO}_{2}$ plume as seen by GOME-2 on 24 April 2015. The three panels show the $\mathrm{SO}_{2}$ vertical column retrieved assuming a plume altitude of $2.5 \mathrm{~km}(\mathrm{~d}), 6 \mathrm{~km}$ (e) and 15 km (f). Lower row: Calbuco $\mathrm{SO}_{2}$ plume as seen by GOME-2 on 25 April 2015.

To deal with the uncertainties and the errors associated with both the satellite retrieval and the numerical analysis, we perform two different simulations. In the first we initialize trajectories from the 23 April image and use the images collected on the 24 and 25 April as a target for the forward trajectory analysis (Simulation 1). $\mathrm{SO}_{2}$ injection height and flux time-series are retrieved 
end of both eruptions. For the second simulation the trajectories are initialized from the 24 April image, while the 23 April is used as a target for the backward trajectories (Simulation 2). In this case the 24 April image is used for the retrieval of plume heights and $\mathrm{SO}_{2}$ fluxes.

In both Simulation 1 and 2 the centre positions of the pixels forming the volcanic plume are used as starting points on the horizontal plane for the trajectory analysis.

We do not utilize a-priori assumptions on $\mathrm{SO}_{2}$ plume altitude, and this information cannot be directly extrapolated from the satellite data, so we initialize trajectories exhaustively from $1 \mathrm{~km}$ to $30 \mathrm{~km}$ asl (upper stratosphere). Assuming an interval of $500 \mathrm{~m}$ between each starting height, we produce a total of 59 trajectories for each pixel. We set the centre position of each pixel as the starting point on the horizontal plane of each trajectory. The time at which the trajectories are initialized is coincident with the time at which the $\mathrm{SO}_{2}$ vertical column was measured for each pixel.

For our test case, the numerical wind data comes from the global ECMWF atmospheric reanalysis ERA Interim dataset with a $0.75^{\circ}$ grid.

After having performed the forward-backward trajectory selection for Simulation 1 and 2, we accept backward trajectories approaching Calbuco vent location $\left(41.33^{\circ} \mathrm{S}, 72.61^{\circ} \mathrm{W}\right)$ using Eq.(1) with the additional constraint from eruption time interval. This means that we consider as acceptable only backward trajectories approaching the vent at a time instant which is consistent with the eruption time interval. This part of the numerical analysis is the same for the two approaches.

For the Calbuco eruptions, the eruption time is well constrained by visual-, satellite- and groundbased observations (SERNAGEOMIN 2015a, 2015b, 2015c; Van Eaton et al., 2016). Thus, for the study of Eruption 1, we use 21:00 and 22:30 UT (22 April) as beginning and end of the 
eruption, while 04:00 and 10:00 UT (23 April) are the values referred to Eruption 2. The umbrella cloud radius is evaluated using the mass eruption rate $(M E R)$ for both Eruption 1 and Eruption 2. Since we do not have a precise estimation of mass eruption rates, we perform a sensitivity analysis on it and we investigate the range $0.3 \cdot 10^{7} \mathrm{~kg} \mathrm{~s}^{-1}-2.7 \cdot 10^{7} \mathrm{~kg} \mathrm{~s}^{-1}$. These values are chosen accordingly to the minimum and maximum MER calculated for the 2015 Calbuco eruptions by previous works (Romero et al., 2016, Castruccio et al., 2016, Van Eaton et al., 2016). The sensitivity analysis is performed using the Design and Analysis toolKit for Optimization and Terascale (DAKOTA) (Adams et al., 2009), selecting a Latin Hypercube approach on a total number of 15 samples (i.e. 15 different values of $M E R$ ). Our numerical results show that using the calculated umbrella cloud radius as a test for acceptable back trajectories works well for Eruption 2 but not for Eruption 1. We believe that the short duration of Eruption 1 and high gas content (see below), together with numerical uncertainties, meant that we need to investigate a wider range of potential radii than $r(t)$ to cover all pixels where $\mathrm{SO}_{2}$ was detected. For Eruption 1, we use an approaching radius varying from 0 to $500 \mathrm{~km}$, whilst for Eruption 2 we calculate $r(t)$ using Eq. (1). In this case, the radius of the umbrella cloud ranges between 0 (beginning of the eruption) and $200 \mathrm{~km}$ (end of the eruption) for $M E R$ equal to $0.3 \cdot 10^{7} \mathrm{~kg} \mathrm{~s}^{-1}$ and between 0 and $360 \mathrm{~km}$ for $M E R$ equal $2.7 \cdot 10^{7} \mathrm{~kg} \mathrm{~s}^{-1}$. The sensitivity analysis performed on MER produces 15 sets of acceptable trajectories for each pixel (one set for each MER). For a given MER, the number of the acceptable trajectories can vary from 0 (i.e. no acceptable trajectories starting from the considered pixel) to 59 (i.e. all the trajectories starting from the considered pixel are acceptable). Depending on the satellite image, from 50.000 to 100.000 trajectories are computed during a single PlumeTraj simulation and about 15.000 trajectories are then selected as acceptable (i.e. the $20 \%$ of the initial number). 


\section{Numerical Results}

Using the previously described technique, we calculate the plume height, the injection height and the injection time for each pixel of the computational domain where $\mathrm{SO}_{2}$ is detected. Following the results are presented for the two simulations. For the first simulation (Simulation 1), Figures 3 and 4 report both the mean values $\left(\bar{h}, \bar{h}_{\text {vent }}\right.$ and $\left.\bar{t}_{\text {vent }}\right)$ and standard deviations $\left(\sigma_{h}, \sigma_{h_{\text {vent }}}\right.$ and $\sigma_{t_{v e n t}}$ ) of plume parameters calculated for each pixel. Figure 3 shows the $\mathrm{SO}_{2}$ cloud emitted from Eruption 1, whilst in Figure 4 we plot the one emitted from Eruption 2. We do not separate apriori the plume of Eruption 1 from that of Eruption 2, but it is the model that, according to the approaching time and radius, distinguishes the two plumes. Figures 3 (a), (d) and 4 (a), (d) show respectively $\bar{h}$ and $\sigma_{h}$ computed for each pixel of the computational domain. Similarly, Figures 3 (b), (e) and 4 (b), (e) report $\bar{h}_{v e n t}$ and $\sigma_{h_{v e n t}}$ respectively, whereas Figures 3 (c), (f) and 4 (c), (f) illustrate $\bar{t}_{\text {vent }}$ and $\sigma_{t_{\text {vent }}}$.

As we can see from Figure 3 and 4 , the whole $\mathrm{SO}_{2}$ plume is split into two clouds, both transported in the same direction (North North-East). The $\mathrm{SO}_{2}$ injected into the atmosphere at the beginning of the eruptive phases travelled furthest from the vent, while pixels closer to vent location contain $\mathrm{SO}_{2}$ emitted at the end of the two eruptions.

Due to low vertical velocity at stratospheric heights, $\bar{h}$ and $\bar{h}_{v e n t}$ are almost coincident (Figure 3 (a), (b) and 4 (a), (b)) and similar result is obtained for $\sigma_{h_{v e n t}}$ and $\sigma_{h}$ (Figure 3 (d), (e) and 4 (d), (e)). For Eruption 1, a mean plume height of $15.7 \pm 0.4 \mathrm{~km}$ both at vent and at satellite overpass is computed, with peaks of $21 \mathrm{~km}$. The mean plume height computed for Eruption 2 is $15 \pm 1.2 \mathrm{~km}$, with some pixels presenting a maximum height of $20 \mathrm{~km}$. Finally, uncertainties on injection time 

with mean values of $12 \mathrm{~min}$ and $30 \mathrm{~min}$ respectively.
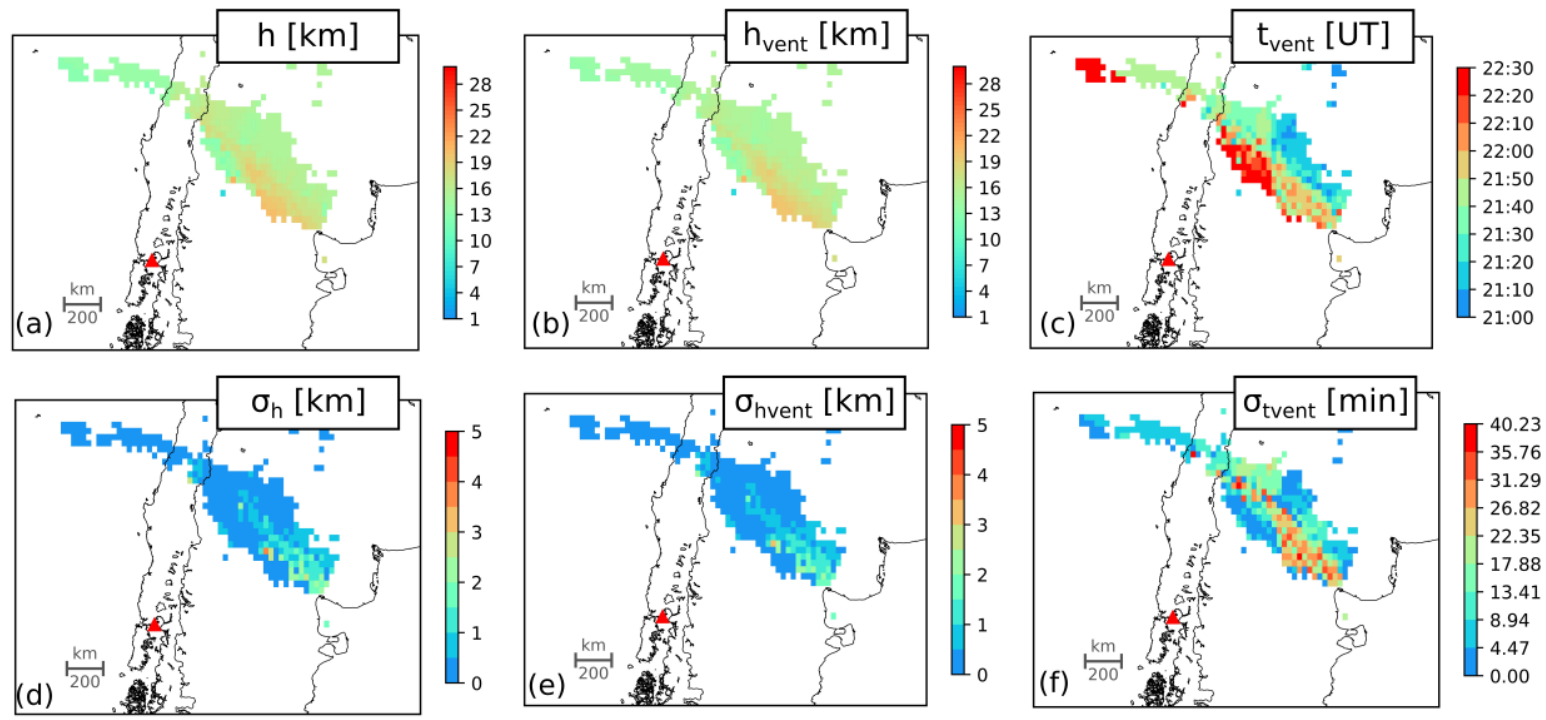

Figure 3 Results PlumeTraj Simulation 1 considering trajectories approaching the vent from 21:00 to 22:30 on 22 April 2015 (Eruption 1). In panels (a), (b), and (c) mean plume height $(\bar{h})$, injection height $\left(\bar{h}_{v e n t}\right)$ and injection time $\left(\bar{t}_{\text {vent }}\right)$ are shown, whereas panels (d), (e) and (f) show the relative standard deviations $\left(\sigma_{h}, \sigma_{h_{v e n t}}\right.$ and $\left.\sigma_{t_{v e n t}}\right)$.
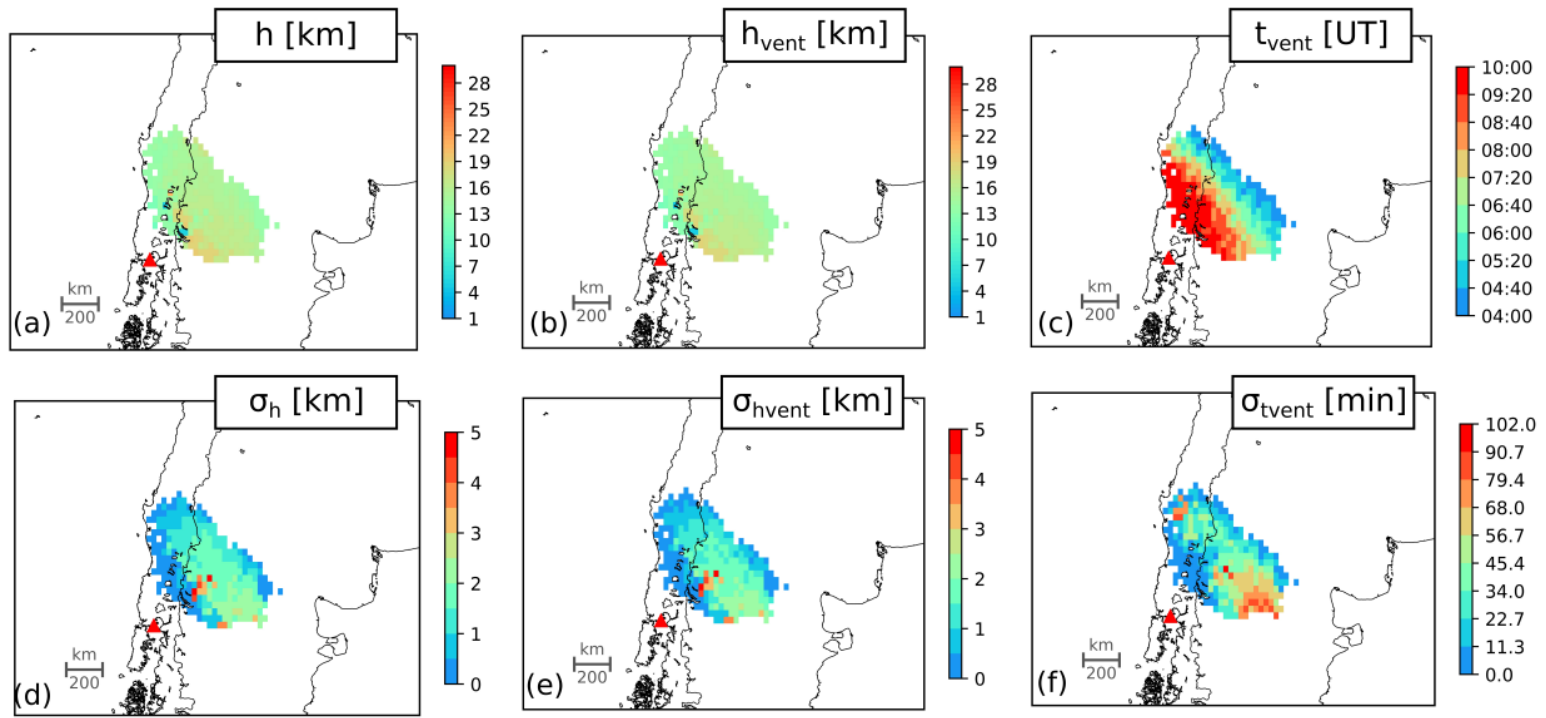

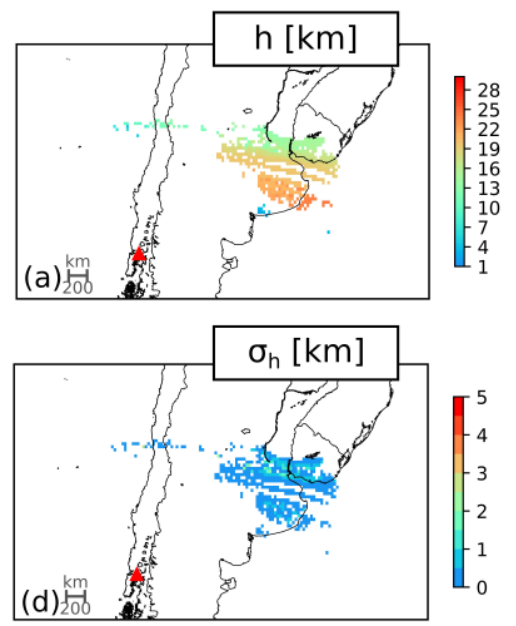
two eruptions.
Figure 4 Results PlumeTraj Simulation 1 considering trajectories approaching the vent from 04:00 to 10:00 on 23 April 2015 (Eruption 2). In panels (a), (b), and (c) mean plume height $(\bar{h})$, injection height $\left(\bar{h}_{\text {vent }}\right)$ and injection time $\left(\bar{t}_{\text {vent }}\right)$ are shown, whereas panels (d), (e) and (f) show the relative standard deviations $\left(\sigma_{h}, \sigma_{h_{\text {vent }}}\right.$ and $\left.\sigma_{t_{\text {vent }}}\right)$.

Figure 5 and 6 show the results of the simulation performed using the 24 April image as input data (Simulation 2). We compute a mean height of $17.5 \pm 0.2 \mathrm{~km}$ and $15 \pm 0.5 \mathrm{~km}$ for the plume emitted during Eruption 1 and Eruption 2 respectively (both at vent and satellite overpass), with top plume height of $24 \mathrm{~km}$. The uncertainties on the injection time range from 0 to $45 \mathrm{~min}$ for Eruption 1 and from 0 to 145 min for Eruption 2, with mean values of 6 and 60 minutes for the

383
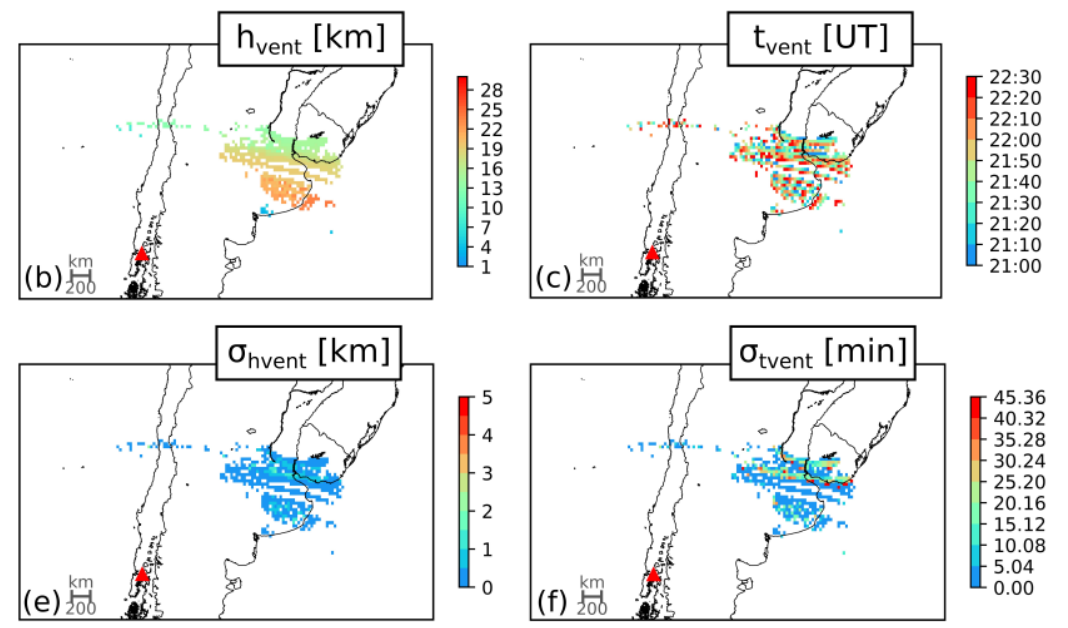

Figure 5 Results PlumeTraj Simulation 2 considering trajectories approaching the vent from 21:00 to 22:30 on 22 April 2015 (Eruption 1). In panels (a), (b), and (c) mean plume height $(\bar{h})$, injection height $\left(\bar{h}_{\text {vent }}\right)$ and injection 

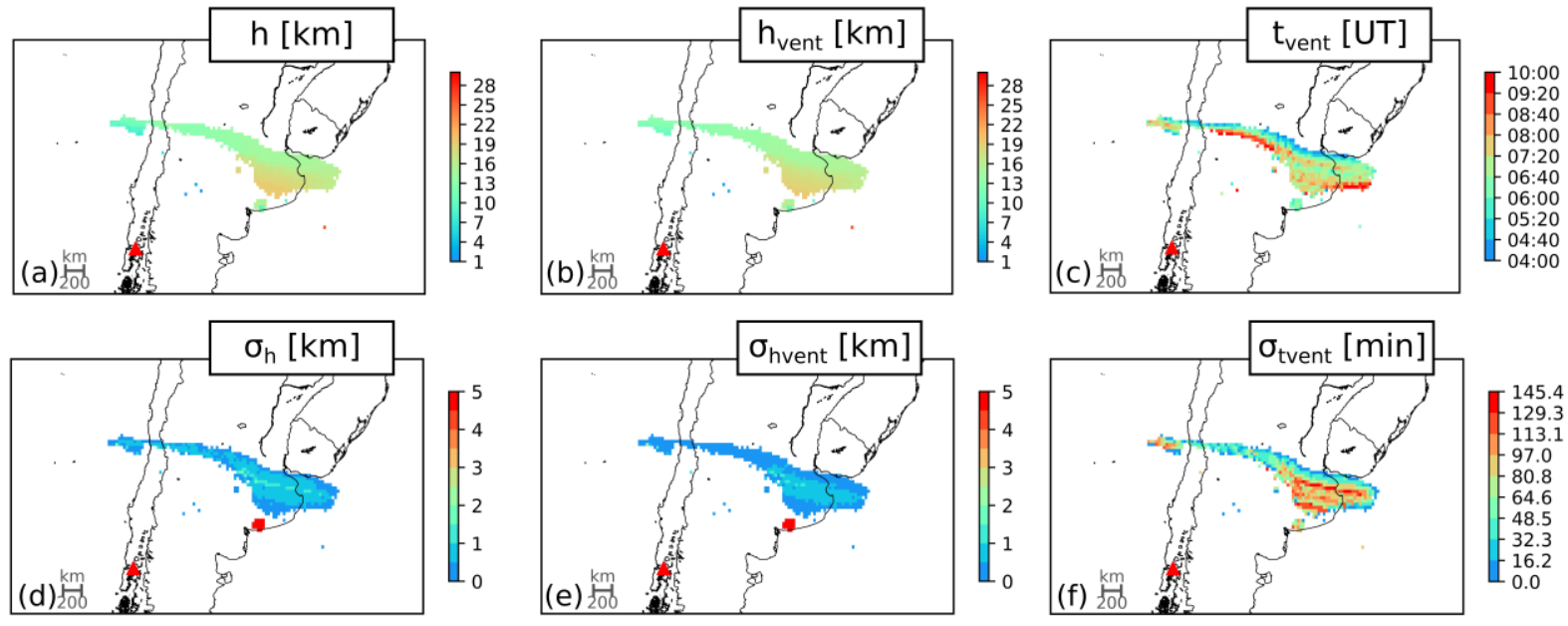

Figure 6 Results PlumeTraj Simulation 2 considering trajectories approaching the vent from 04:00 to 10:00 on 23 April 2015 (Eruption 2). In panels (a), (b), and (c) mean plume height $(\bar{h})$, injection height $\left(\bar{h}_{\text {vent }}\right)$ and injection time $\left(\bar{t}_{\text {vent }}\right)$ are shown, whereas panels (d), (e) and (f) show the relative standard deviations $\left(\sigma_{h}, \sigma_{h_{\text {vent }}}\right.$ and $\left.\sigma_{t_{\text {vent }}}\right)$.

To test the consistency of our results we use our injection height time-series to initialize a dispersal simulation using the HYSPLIT dispersion module. Puffs of gas are released from the Calbuco vent location at each retrieved $\bar{h}_{v e n t}$ and $\bar{t}_{v e n t}$ from an area which is consistent we the growth of the umbrella radius at that height and time during the eruption. The position of the plume is captured in agreement with the satellite measurement on 24, 25, 26, 27 and 28 April 2015 as shown in Figure 7. Panels from (a) to (f) show GOME-2 images of the Calbuco plume from 23 to 28 April 2015, while in panels from (g) to (n) our dispersal simulation is presented. A 401 good match between the plume as captured by GOME-2 and as retrieved from our simulation can be observed especially for the part of the cloud located at the highest heights (from 15 to 25 $\mathrm{km}$ ) where the bulk of the $\mathrm{SO}_{2}$ appears to be located. 


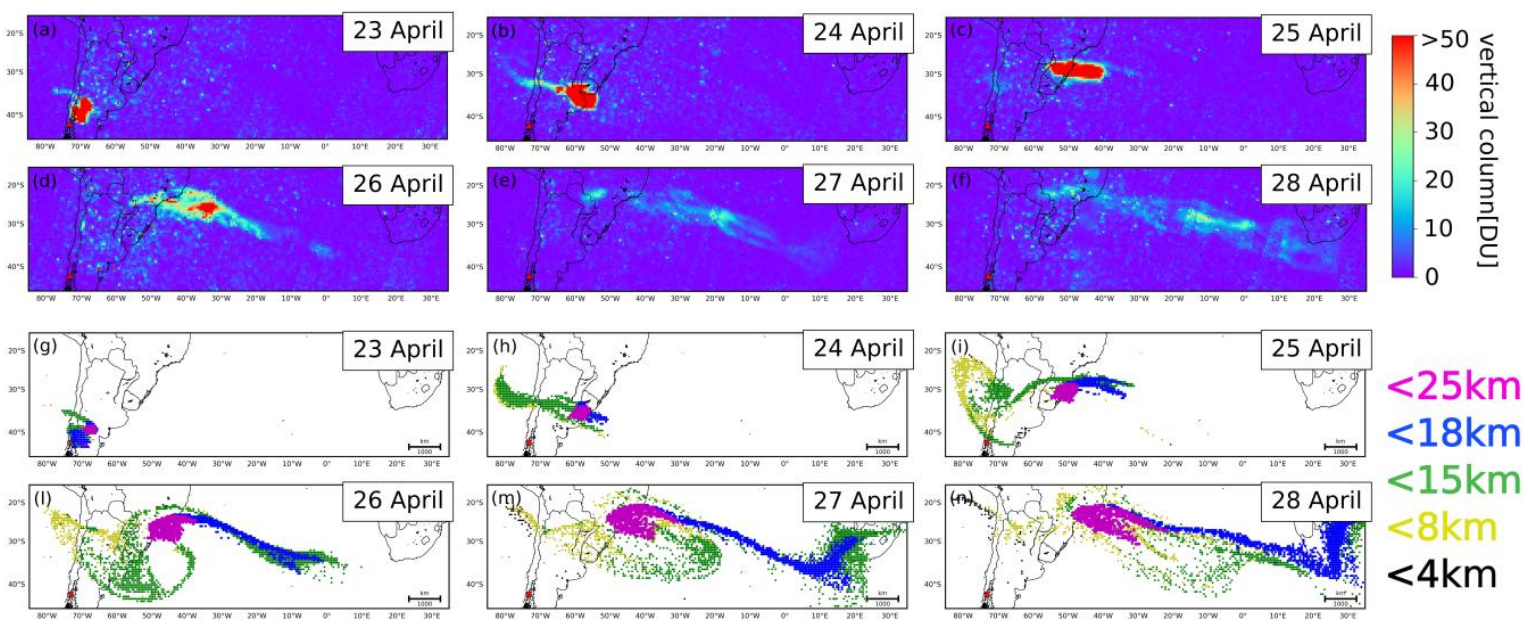

404

Figure 7 Panels from (a) to (f) show the Calbuco $\mathrm{SO}_{2}$ plume as measured by GOME-2 from 23 to 28 April 2015. Panels from (g) to (n) present the results of the dispersal simulation performed using the retrieved injection time and height as input parameters. The altitudes at which the plume is located are shown with different colours from 0 to 25 $\mathrm{km}$.

Plume height retrievals from PlumeTraj are consistent with those derived from analysis of both the tephra deposit and remote sensing techniques. Following the method of maximum clast diameters (Carey and Sparks, 1986), Romero et al., (2016) computed maximum column heights of 15.4 $\pm 3.08 \mathrm{~km}$ during Eruption 1 and the first phase of Eruption 2, while a decrease during the last phase of Eruption 2 emerges with heights of $12-13 \mathrm{~km}$. Similar values are reported by Castruccio et al., (2016) with the only difference of proposing an increase in column height at the end the Eruption 2. These values are also in agreement with that presented by Van Eaton et al., (2016) considering the growth of the umbrella cloud (14.5-15.5 km for Eruption 1 and 16.9$17.3 \mathrm{~km}$ for Eruption 2). The main difference we notice from these deposit estimates of plume height compared with those performed by our numerical simulation is the absence of heights higher than $20 \mathrm{~km}$. However, Vidal et al., (2017) show, using a dual polarized weather radar, the 
421 main column located between 7 and $15 \mathrm{~km}$ for Eruption 2, with a maximum value of $23 \mathrm{~km}$ asl,

422 in agreement with our estimations for plume heights. Finally, using spaceborne observations in

423 the microwave, thermal infrared and visible wavelength Marzano et al., (2018) show a plume

424 height between $15 \mathrm{~km}$ and $20 \mathrm{~km}$ with a maximum value of $21 \mathrm{~km}$ asl.

425

\subsection{Masses estimation from numerical results and $\mathrm{SO}_{2}$ flux time-series}

Our retrieval of plume height time-series opens the possibility of quantifying mass eruption rate time-series, and to compare these data with field data. For the Calbuco eruptions, separation of volcanic ash and $\mathrm{SO}_{2}$ gas has not been observed, so retrieved $\mathrm{SO}_{2}$ injection heights are representative of column height evolution during the eruptions. Column height is primary controlled by the thermal buoyancy of the erupted material, which is a function of the mass flux supplied during the eruption (Sparks 1997). We use our mean injection height time-series to calculate a mean mass eruption rate $(M E R)$ and we use it to evaluate the mass of erupted solid material $(M)$. From Simulation $1, M E R$ and $M$ are equal to $1.9 \pm 0.55 \cdot 10^{7} \mathrm{~kg} \mathrm{~s}^{-1}$ and $10.6 \pm 3 \cdot 10^{4}$ kt for Eruption 1 and $1.73 \pm 0.34 \cdot 10^{7} \mathrm{~kg} \mathrm{~s}^{-1}$ and $37.4 \pm 7 \cdot 10^{4} \mathrm{kt}$ for Eruption 2. From Simulation 2, they are equal to $3.05 \pm 0.21 \cdot 10^{7} \mathrm{~kg} \mathrm{~s}^{-1}$ and $16.4 \pm 1.1 \cdot 10^{4} \mathrm{kt}$ for Eruption 1 and $1.51 \pm 0.42 \cdot 10^{7} \mathrm{~kg}$ $\mathrm{s}^{-1}$ and $32.6 \pm 9.1 \cdot 10^{4} \mathrm{kt}$ for Eruption 2. From these results, we compute a mean $M E R$ of $2.51 \pm 0.60 \cdot 10^{7} \mathrm{~kg} \mathrm{~s}^{-1}$ for Eruption 1 and of $1.62 \pm 0.54 \cdot 10^{7} \mathrm{~kg} \mathrm{~s}^{-1}$ for Eruption 2 and we infer $13.5 \pm 3.2 \cdot 10^{4} \mathrm{kt}$ of solid material emitted during Eruption 1 and $35.0 \pm 11.7 \cdot 10^{4} \mathrm{kt}$ during Eruption 2.

These values are in good agreement with those from Castruccio et al., (2016) which report $8 \cdot 10^{4}$ kt for Eruption 1 and $32 \cdot 10^{4} \mathrm{kt}$ for Eruption 2. Our satellite-based interpretation seems to confirm the eruptive scenario proposed by Castruccio et al., (2016) which assign the first of the four 
443 layers of the deposit to the first eruption and the other three to the second one. Differently,

444 Romero et al., (2016) assign the first two layers to Eruption 1 and the other two to Eruption 2.

445 Despite this, the two authors agree on the general stratigraphy.

446 Assuming a magma density of $\sim 2500 \mathrm{~kg} \mathrm{~m}^{-3}$, we compute a deposit dense rock equivalent

447 (DRE) of $0.198 \pm 0.050 \mathrm{~km}^{3}$, with $0.055 \pm 0.013 \mathrm{~km}^{3}$ resulting from Eruption 1 and $0.143 \pm 0.048$

$448 \quad \mathrm{~km}^{3}$ from Eruption 2.

449 Finally, we use our retrieved plume heights to correct the $\mathrm{SO}_{2}$ vertical columns as computed 450 from space. Indeed, $\mathrm{SO}_{2}$ vertical columns retrieved from satellite data depend on several factors, 451 such as plume height, $\mathrm{SO}_{2}$ lifetime and satellite sensors signal saturation. In our test case, the 452 effect related to $\mathrm{SO}_{2}$ lifetime can be neglected. Indeed, lifetime of volcanic $\mathrm{SO}_{2}$ injected into the 453 stratosphere depends primarily on injection altitude and can vary from 8-9 days for $11 \mathrm{~km}$ height plumes (Krotkov et al., 2010) to 25 days for higher injection altitudes (Guo et al., 2004). For the 455 Calbuco $\mathrm{SO}_{2}$ cloud an e-folding time of 11 days has been computed by Bègue et al., (2017).

$456 \mathrm{SO}_{2}$ retrievals from GOME-2 report vertical columns for each pixel at 3 hypothetical plume 457 heights of $2.5 \mathrm{~km}, 6 \mathrm{~km}, 15 \mathrm{~km}$ (Figure 2(a)-(c)). We interpolate $\mathrm{SO}_{2}$ column amounts between these three heights and use our calculated mean $\mathrm{SO}_{2}$ height $(\bar{h})$ to correct the column amount.

459 From Simulation 1, we compute $0.085 \mathrm{Tg}$ and $0.090 \mathrm{Tg}$ of $\mathrm{SO}_{2}$ released during Eruption 1 and 460 Eruption 2 respectively. From Simulation 2 we evaluate $0.195 \mathrm{Tg}$ of $\mathrm{SO}_{2}$ emitted during 461 Eruption 1 and $0.219 \mathrm{Tg}$ during Eruption 2. We compute a total $\mathrm{SO}_{2}$ mass loading of $4620.295 \pm 0.045 \mathrm{Tg}$, with $0.140 \pm 0.033 \mathrm{Tg}$ produced by Eruption 1 and $0.155 \pm 0.031 \mathrm{Tg}$ by 463 Eruption 2. A major source of uncertainty for this result is represented by the possible 464 underestimation of the $\mathrm{SO}_{2}$ loading computed from the GOME-2 data. Signal saturation due to 465 high $\mathrm{SO}_{2}$ column amounts and presence of volcanic ash can affect the satellite retrieval. Thus, 
466 our $\sim 0.3 \mathrm{Tg}$ of $\mathrm{SO}_{2}$ emitted can be seen as a minimum value. However, Bègue et al., (2017) 467 show that the atmospheric $\mathrm{SO}_{2}$ loading computed from the IASI data varies from $0.1 \mathrm{Tg}$ on 23 468 April 2015 to a maximum amount of $0.4 \mathrm{Tg}$ on 25 April, in agreement with our estimate.

469 Finally, by associating the injection time at the vent $\left(t_{\text {vent }}\right)$ for each pixel $\mathrm{SO}_{2}$ mass loading, we 470 calculate $\mathrm{SO}_{2}$ flux time-series, Figure 8.

471

472

473

474

475 


\section{Simulation 1}
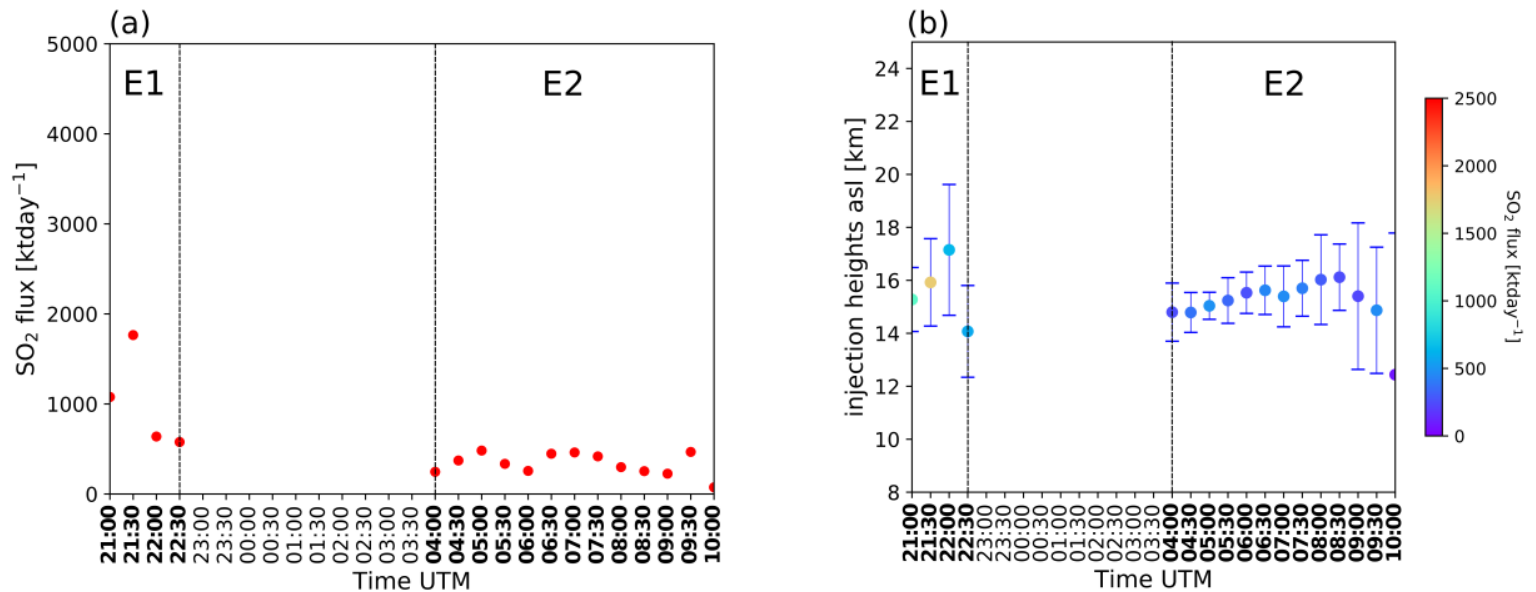

Simulation 2
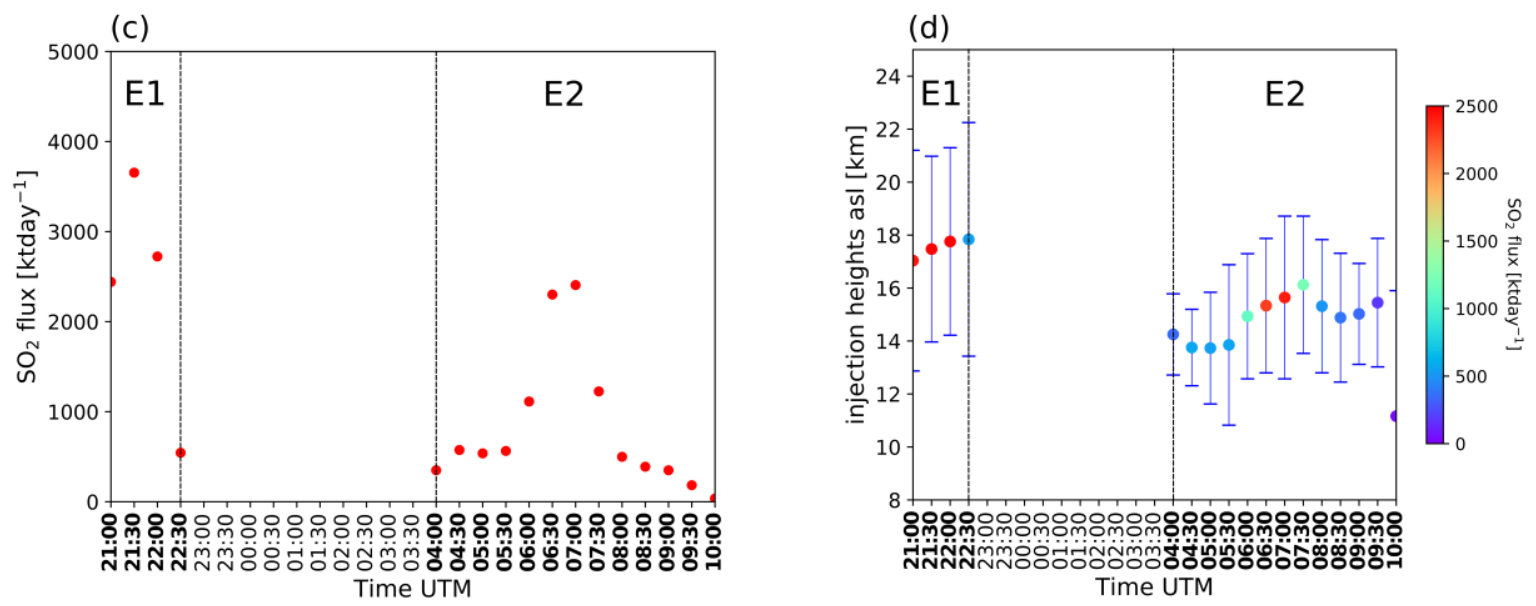

\section{Simulation $1 \& 2$}

(e)

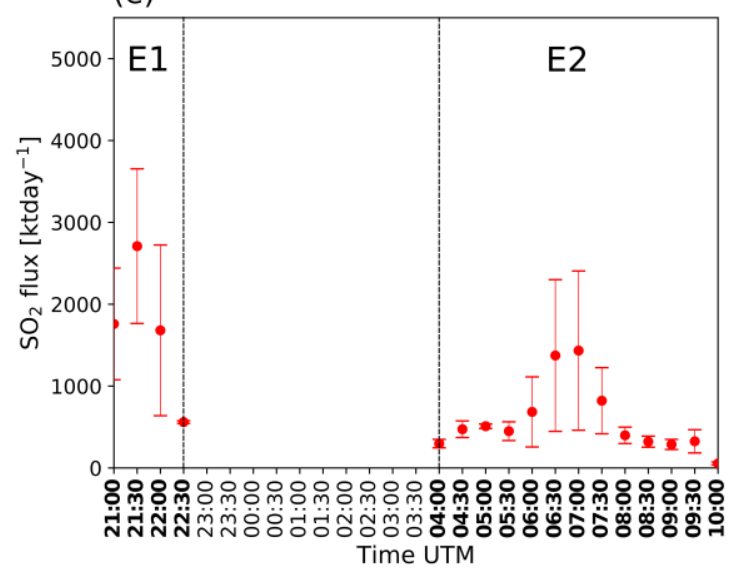

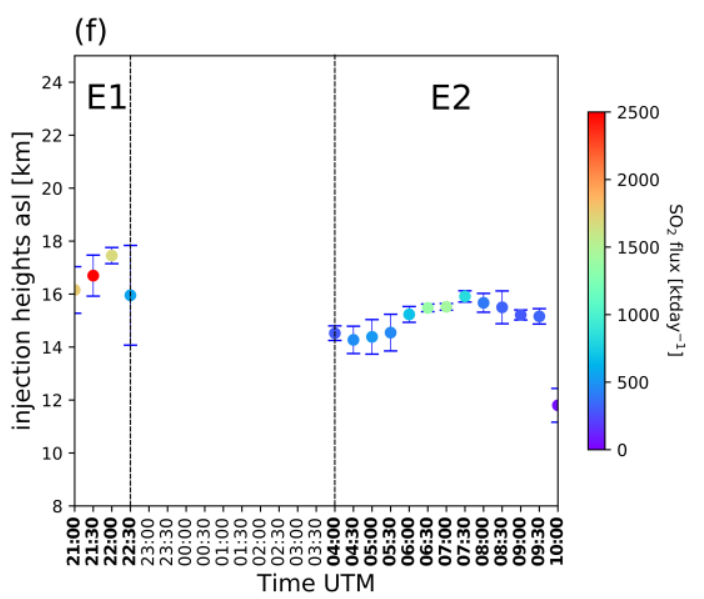


Figure 8 Upper row: $\mathrm{SO}_{2}$ fluxes and injection height time-series resulting from Simulation 1. Middle row: $\mathrm{SO}_{2}$ fluxes and injection height time-series resulting from Simulation 2. Lower row: $\mathrm{SO}_{2}$ fluxes injection height timeseries resulting from the combination of the two simulations.

The similar amount of $\mathrm{SO}_{2}$ released during the two eruptions and the different duration of the events $\left(1.5 \mathrm{~h}\right.$ and $6 \mathrm{~h}$ ) are reflected in the average $\mathrm{SO}_{2}$ fluxes. Eruption 1 produced an intense gas emission with mean flux of $2200 \pm 520 \mathrm{kt} \mathrm{day}^{-1}$, while a smoother gas released can be observed for Eruption 2 together with a lower mean flux of $620 \pm 120 \mathrm{kt} \mathrm{day}^{-1}$. Comparing $\mathrm{SO}_{2}$ flux and injection height time-series, two different volcanic processes driving Eruption 1 and 2 emerge. This is reflected in the similar total amount of $\mathrm{SO}_{2}(\sim 150 \mathrm{kt})$ released in different time scale $(1.5 \mathrm{~h}$ and $6 \mathrm{~h})$ but in a similar range of altitudes $(14-18 \mathrm{~km})$.

\section{Estimate of $\mathrm{SO}_{2}$ in Magma: method and results}

To quantify the atmospheric $\mathrm{SO}_{2}$ yield from the Calbuco eruptions, we adopt the well-established petrological method (Devine et al., 1984). This consists of measuring the sulfur concentration in glassy melt inclusions, which represent the undegassed melt, and in matrix glasses, which instead represent the degassed melt. The mass of sulfur released is then calculated by the difference of the two concentrations multiplied by the mass of erupted material. A correction considering the mass fraction of syn- or post-eruptive crystals can also be considered. To compare our satellite estimates of $\mathrm{SO}_{2}$ mass loadings with elemental sulfur concentrations, it is useful to convert petrological estimates of sulfur mass loadings into $\mathrm{SO}_{2}$ mass loadings. This is readily achieved by multiplying by two, following the molecular weight of $\mathrm{SO}_{2}\left(64 \mathrm{~g} \mathrm{~mol}^{-1}\right)$ and atomic weight of 
499 sulfur $\left(32 \mathrm{~g} \mathrm{~mol}^{-1}\right)$. Thus, according to the petrological method, the $\mathrm{SO}_{2}$ loading released into the 500 atmosphere during an individual eruption $\left(m\left(\mathrm{SO}_{2}\right)_{P E T R}\right)$ can be expressed as:

$501 \quad m\left(S O_{2}\right)_{P E T R}=M \cdot\left(S_{M I}-S_{M G}\right) \cdot \frac{M W\left(S O_{2}\right)}{M W(S)} \cdot(1-C F)$,

where $M$ is the mass of erupted material, $S_{M I}$ and $S_{M G}$ are the sulfur concentrations measured in melt inclusions and matrix glass, $\mathrm{MW}\left(\mathrm{SO}_{2}\right)$ and $\mathrm{MW}(\mathrm{S})$ are the molecular weights of $\mathrm{SO}_{2}$ and $\mathrm{S}$ and $C F$ is a coefficient accounting for the volume of syn- or post-eruptive crystals in the melt.

This method has been largely applied often in conjunction with satellite estimates of atmospheric $\mathrm{SO}_{2}$ yield to investigate sulfur degassing mechanisms (Sharma et al., 2004; Sigmarsson et al., 2013). Depending on magma type, volcanic setting and eruption style, the atmospheric $\mathrm{SO}_{2}$ yield retrieved from space can exceed the one resulting from the Petrological Method by up to one order of magnitude (Wallace 2001, Danyushevsky et al., 2002). For explosive eruptions, this behavior, which is known as "excess $\mathrm{SO}_{2}$ ", has been explained with the presence of a preeruptive exsolved $\mathrm{SO}_{2}$ gas phase present at depth before the beginning of the eruption. From these analyses we can examine if excess $\mathrm{SO}_{2}$ was produced during the Calbuco eruptions.

The tephra deposit formed by the Calbuco eruptions is composed by four layers named A, B, C and D. According to Castruccio et al., (2016), we consider scoriae of the first layer (layer A) as produced by Eruption 1 and those from the other three layers (layers B, C and D) from Eruption 2. Sulfur concentrations in the MIs of Eruption 1 (scoriae of layer A) vary from 240 to $520 \mathrm{ppm}$ (see Table S1 in the supplementary material), and sulfur contents in the MIs of Eruption 2 (scoriae of layers B, C and D) range between 270 and $590 \mathrm{ppm}$. Low values of sulfur are measured in the matrix glasses of the scoriae erupted from both eruptions, ranging between 30 and $150 \mathrm{ppm}$ (these values are close to the detection limit of the electron microprobe). From these analyses, the amount of sulfur dissolved in the melt is equal to $351 \pm 98$ ppm for Eruption 1 
and $412 \pm 101 \mathrm{ppm}$ for Eruption 2. For the residual melt (matrix glass) we evaluate $93 \pm 6 \mathrm{ppm}$ for Eruption 1 and 92 \pm 40 ppm for Eruption 2.

In order to evaluate the atmospheric $\mathrm{SO}_{2}$ yield as shown in Eq. (9), we consider $C F$ equal to 0.5 (i.e. we account for a 50 vol.\% of crystals in the melt, from personal communication with Fabio Arzilli). For Eruption $1 \mathrm{M}, S_{M I}$ and $S_{g m}$ are equal to $13.5 \pm 3.2 \cdot 10^{4} \mathrm{kt}, 351 \pm 98 \mathrm{ppm}$ and $93 \pm 6$ ppm, while for Eruption 2 they are equal $35.0 \pm 11.7 \cdot 10^{4} \mathrm{kt}, 412 \pm 101 \mathrm{ppm}$ and $92 \pm 40 \mathrm{ppm}$. From Eq.(9), the $\mathrm{SO}_{2}$ yield emitted during Eruption 1 is $35 \pm 16 \mathrm{kt}$, while the one emitted during Eruption 2 is $112 \pm 53 \mathrm{kt}$.

\section{Discussion}

Excess $\mathrm{SO}_{2}$ has been invoked to explain a large body of evidence where satellite detection of volcanic $\mathrm{SO}_{2}$ plumes demonstrated that the amount of $\mathrm{SO}_{2}$ released into the atmosphere during volcanic eruptions, both explosive and effusive, can exceed that resulting from syneruptive volatile exsolution (Devine et al., 1984).

The process which produces such excess $\mathrm{SO}_{2}$ degassing depends on tectonic setting, magma type, magma evolution and eruption style and it appears to be particularly characteristic of explosive eruptions of intermediate and silicic magma in subduction zone settings (Andres et al., 1991), such as Calbuco. For explosive eruptions, excess degassing is caused by the presence of pre-eruptive exsolved bubbles accumulated at the top of the magma chamber where the erupted magma is also located. Pre-eruptive bubbles can be supplied to erupted magma by the intrusion of bubble-bearing magma into a magma chamber, by crystallization of part of the magma and subsequent bubble formation or by the presence of a sulfur-rich basaltic magma located beneath the silicic one (Shinohara, 2008). Once pre-eruptive bubbles are formed they migrate at the top 
544 of the chamber due to buoyancy forces and form a gas rich foam which, once erupted, produces

545 the observed excess degassing. We highlight that excess $\mathrm{SO}_{2}$ degassing is likely to be associated

546 with excess degassing of other volcanic gas species, such as the more abundant $\mathrm{H}_{2} \mathrm{O}$ and $\mathrm{CO}_{2}$

547 (Edmonds et al., 2010), and that this may represent a large but unconstrained contribution to the 548 global geological carbon cycle.

549 Our PlumeTraj results show that the $\mathrm{SO}_{2}$ flux produced during Eruption 1 was three times higher 550 than that of Eruption 2 (2200 $\mathrm{ktday}^{-1}$ and $620 \mathrm{ktday}^{-1}$ respectively), indicating a much more gas551 rich magma in the first eruption. Using the PlumeTraj mass eruption rates we can infer the 552 original $\mathrm{SO}_{2}$ contents of magmas required to produce the observations: $0.10 \mathrm{wt} \%$ for Eruption 1 and $0.04 \mathrm{wt} \%$ for Eruption 2. Such a contrast in original $\mathrm{SO}_{2}$ contents of magmas erupted so 554 close in time suggests that the most likely explanation is not different dissolved volatile contents, but a larger role for magma chamber vapour segregation contributing to Eruption 1 than Eruption 2. We highlight that this inference on the subsurface process is produced purely through application of PlumeTraj to satellite imagery. In order to quantify the pre-accumulated gas phase in Calbuco's 2015 eruptions, we compare the $559 \mathrm{SO}_{2}$ yield derived from our numerical satellite-based technique, with the one resulting from 560 petrological estimates, and we calculate the excess $\mathrm{SO}_{2}$ as the difference between the mass of $561 \mathrm{SO}_{2}$ inferred from space and the one inferred from the petrological analysis. For Eruption 1, we 562 find $105 \pm 36 \mathrm{kt}$ of excess $\mathrm{SO}_{2}$, whereas for Eruption $243 \pm 62 \mathrm{kt}$, see Table 1.

\begin{tabular}{ccccccc}
\hline & $\boldsymbol{M}$ & $\boldsymbol{S}_{\boldsymbol{M I}}$ & $\boldsymbol{S}_{\boldsymbol{g m}}$ & $\boldsymbol{m}\left(\boldsymbol{S O}_{2}\right)_{\text {PETR }}$ & $\boldsymbol{m}\left(\boldsymbol{S O}_{2}\right)_{\boldsymbol{S A T}}$ & $\boldsymbol{m}\left(\boldsymbol{S O}_{2}\right)_{\boldsymbol{e x}}$ \\
\hline E1 & $13.5 \pm 3.2 \cdot 10^{4} \mathrm{kt}$ & $351 \pm 98 \mathrm{ppm}$ & $93 \pm 6 \mathrm{ppm}$ & $35 \pm 16 \mathrm{kt}$ & $140 \pm 33 \mathrm{kt}$ & $105 \pm 36 \mathrm{kt}$
\end{tabular}




\section{E2 $\quad 35.0 \pm 11.7 \cdot 10^{4} \mathrm{kt} \quad 412 \pm 101 \mathrm{ppm} \quad 92 \pm 40 \mathrm{ppm} \quad 112 \pm 53 \mathrm{kt} \quad 155 \pm 31 \mathrm{kt} \quad 43 \pm 62 \mathrm{kt}$}

$M$, mass of erupted solid material as estimated from our numerical method.

$S_{M I}, S_{g m}$, concentration of sulfur in melt inclusions and glassy matrix respectively.

$m\left(S O_{2}\right)_{P E T R}=M \cdot\left(S_{M I}-S_{g m}\right) \cdot \frac{M W\left(S O_{2}\right)}{M W(S)} \cdot(1-C F)$, where $M$ is the mass of erupted material, $M W\left(S O_{2}\right)$ and $M W(S)$ are the molar weights of $\mathrm{SO}_{2}$ and S equal to $64 \mathrm{~g} \mathrm{~mol}^{-1}$ and $32 \mathrm{~g} \mathrm{~mol}^{-1}$ and $C F$ is a coefficient accounting for 50 vol.\% of crystals.

$m\left(\mathrm{SO}_{2}\right)_{S A T}$, atmospheric sulfur yield as retrieved from satellite data.

$m\left(\mathrm{SO}_{2}\right)_{e x}=m\left(\mathrm{SO}_{2}\right)_{S A T}-m\left(\mathrm{SO}_{2}\right)_{P E T R}$, mass of pre-eruptive exsolved $\mathrm{SO}_{2}$.

Table 1 Calculation of $\mathrm{SO}_{2}$ budget from Calbuco eruptions

This demonstrates that $75 \pm 26 \%$ of the $\mathrm{SO}_{2}$ emitted during Eruption 1 and $28 \pm 40 \%$ of $\mathrm{SO}_{2}$ emitted during Eruption 2 were already present as part of the pre-eruptive exsolved gas phase. From the petrological results, the weight percent of $\mathrm{SO}_{2}$ lost from the erupted magma is $\sim 0.03$ wt $\%$ for both the eruptions. Comparing this value with those calculated from PlumeTraj $(0.10$ $\mathrm{wt} \%$ for Eruption 1 and $0.04 \mathrm{wt} \%$ for Eruption 2), we find an excess of $0.07 \mathrm{wt} \%$ of $\mathrm{SO}_{2}$ for Eruption 1 and $0.01 \mathrm{wt} \%$ for Eruption 2. Within the uncertainties, we conclude that excess $\mathrm{SO}_{2}$ is present for Eruption 1, while Eruption 2 ranges between no excess $\mathrm{SO}_{2}$ and an amount of already degassed $\mathrm{SO}_{2}$ which is in, any case, lower in compare with Eruption 1.

To consolidate this result, additional PlumeTraj simulations have been performed using different wind-fields (see the Supplementary Material). We found an overall agreement between all the analyses, and the presence of excess $\mathrm{SO}_{2}$ appear to be confirmed. This result is not affected by the possible underestimation of the $\mathrm{SO}_{2}$ loading as computed from the GOME-2 dataset. In fact, a higher SO2 loading computed from space would result in a higher weight percent of $\mathrm{SO}_{2}$ computed by PlumeTraj, while the outcomes of the petrological analysis would be the same. 
Thus, for atmospheric $\mathrm{SO}_{2}$ yield higher than that retrieved by GOME-2 $(\sim 0.3 \mathrm{Tg})$ the $\mathrm{SO}_{2}$ excess would be confirmed for the two eruptions.

591 From the combined satellite and petrological analysis, we conclude that Eruption 1 was triggered 592 by the overpressure caused by the accumulation of pre-eruptive bubbles at the top of the magma 593 chamber. This resulted in a gas-rich impulsive eruption. The subsequent pressure release allowed 594 the exsolution of new bubbles which, together with the pre-eruptive ones (less abundant than 595 those triggering Eruption 1), powered Eruption 2 during which a larger amount of magma was 596 released in compare to Eruption 1.

\section{Conclusions}

We have developed the PlumeTraj technique to retrieve $\mathrm{SO}_{2}$ flux and eruption plume height 599 time-series of explosive eruptions. PlumeTraj combines satellite imagery of volcanic $\mathrm{SO}_{2}$ plumes 600 with independent observations of the timing of the eruption and forward and backward trajectory 601 simulations performed through the HYSPLIT software, can be generally applied, and used to 602 investigate $\mathrm{SO}_{2}$ emissions during any type of volcanic eruption. The algorithm is 603 computationally efficient and can be run in an automated manner in <12 hours. Retrieved plume 604 heights are used to correct the assumption that the whole plume is located at the same 605 hypothetical altitude, thus producing corrected $\mathrm{SO}_{2}$ vertical columns.

606 Here, we quantified $\mathrm{SO}_{2}$ emissions from the recent April 2015 Calbuco eruptions using imagery 607 from the GOME-2 satellite sensor. It is worth to notice that in 2017 the TROPOspheric 608 Monitoring Instrument (TROPOMI) has been launched aboard the Copernicus Sentinel-5 609 Precursor $(\mathrm{S}-5 \mathrm{P})$ platform. TROPOMI will open the possibilities of $\mathrm{SO}_{2}$ retrievals at higher 610 spatial resolution than before (Theys et al., 2017) and the investigation of volcanic processes 
611 through satellite data can be further improved with the use of more accurate $\mathrm{SO}_{2}$ retrievals

612 coming from this instrument.

613 In the present paper, we retrieved $\mathrm{SO}_{2}$ injection height and flux time-series together with masses

614 of erupted material and we used them to unravel triggering mechanisms and volcanic processes

615 of the Calbuco eruptions. Comparing our results in terms of atmospheric $\mathrm{SO}_{2}$ yield and masses of

616 solid material released during the eruptions, we inferred the presence of different exsolved

617 volatile phase at depth between the two eruptions. Electron microprobe analyses performed on

618 Calbuco tephra samples confirmed our conclusions, validating our hypothesis made just from our

619 numerical technique. One of the main results of this study is the evidence that exsolved $\mathrm{SO}_{2}$ was

620 present before the onset of the eruptions, highlighting that other volatiles $\left(\mathrm{H}_{2} \mathrm{O}, \mathrm{CO}_{2}\right.$ and $\left.\mathrm{Cl}\right)$

621 were already exsolved at the same pre-eruptive conditions (Wallace 2005). This lead us to

622 conclude that the overpressure due to pre-eruptive exsolved volatiles (not only $\mathrm{SO}_{2}$, but probably

623 also $\mathrm{H}_{2} \mathrm{O}$ and $\mathrm{CO}_{2}$ ) may have played a role in the triggering mechanisms of both the sub-Plinian 624 eruptions.

\section{Acknowledgements}

626

627 The research leading to these results has received funding from the European Research Council

628 under the European Union's Seventh Framework Programme (FP/2007-2013)/ERC Grant 629 Agreement no. 279802. We gratefully acknowledge funding support from RCUK NERC

630 DisEqm project (NE/N018575/1). We wish to thank Daniele Morgavi and Jorge E. Romero for 631 providing the Calbuco tephra samples and Jonathan Fellowes for helping with the petrological 632 analyses. 


\section{References}

Adams, B. M., Bohnhoff, W. J., Dalbey, K. R., Eddy, J. P., Eldred, M. S., Gay, D. M., Haskell, K., Hough, P. D. and Swiler, L. P.: DAKOTA, a multilevel parallel object-oriented framework for design optimization, parameter estimation, uncertainty quantification, and sensitivity analysis: version 5.0 user's manual, Sandia National Laboratories, Tech. Rep. SAND2010-2183, doi:DOI: 10.2172/991842, 2009.

Andres, R. J., Rose, W. I., Kyle, P. R., DeSilva, S., Francis, P., Gardeweg, M. and Roa, H. M.: Excessive sulfur dioxide emissions from Chilean volcanoes. Journal of Volcanology and Geothermal Research, 46(3-4), pp.323-329, 1991.

Bègue, N., Vignelles, D., Berthet, G., Portafaix, T., Payen, G., Jégou, F., Benchérif, H., Jumelet, J., Vernier, J.-P., Lurton, T., Renard, J.-B., Clarisse, L., Duverger, V., Posny, F., Metzger, J.-M., and Godin-Beekmann, S.: Long-range isentropic transport of stratospheric aerosols over Southern Hemisphere following the Calbuco eruption in April 2015, Atmos. Chem. Phys. Discuss., https://doi.org/10.5194/acp-2017-544, 2017.

Boichu, M., Menut, L., Khvorostyanov, D., Clarisse, L., Clerbaux, C., Turquety, S. and Coheur, P.-F.: Inverting for volcanic $\mathrm{SO}_{2}$ flux at high temporal resolution using spaceborne plume imagery and chemistry-transport modelling: the 2010 Eyjafjallajökull eruption case-study, Atmospheric Chemistry and Physics, 13(17), 8569-8584, doi:10.5194/acp-13-8569-2013, 2013.

Brenot, H., Theys, N., Clarisse, L., Van Geffen, J., Van Gent, J., Van Roozendael, M., Van Der A, R., Hurtmans, D., Coheur, P.-F. and Clerbaux, C.: Support to Aviation Control Service (SACS): an online service for near real-time satellite monitoring of volcanic plumes, Natural hazards and 
655

656

657

658

659

660

661

662

663

664

665

666

667

668

669

670

671

672

673

674 earth system sciences, 14(5), 1099-1123, doi:10.5194/nhess-14-1099-2014, 2014.

Campion, R.: New lava lake at Nyamuragira volcano revealed by combined ASTER and OMI SO2 measurements, Geophys. Res. Lett., 41, 7485-7492, doi:10.1002/2014GL061808, 2014.

Carboni, E., Grainger, R., Walker, J., Dudhia, A. and Siddans, R.: A new scheme for sulphur dioxide retrieval from IASI measurements: application to the Eyjafjallajökull eruption of April and May 2010, Atmospheric Chemistry and Physics, 12(23), 11417-11434, doi:10.5194/acp-1211417-2012, 2012.

Carboni, E., Grainger, R. G., Mather, T. A., Pyle, D. M., Thomas, G. E., Siddans, R., Smith, A. J. A., Dudhia, A., Koukouli, M. E., and Balis, D.: The vertical distribution of volcanic $\mathrm{SO}_{2}$ plumes measured by IASI, Atmos. Chem. Phys., 16, 4343-4367, https://doi.org/10.5194/acp-16-4343-2016, 2016.

Carey, S. and Sparks, R. S. J.: Quantitative models of the fallout and dispersal of tephra from volcanic eruption columns, Bulletin of Volcanology, 48(2), 109-125, doi:10.1007/BF01046546, 1986.

Carn, S. A., Krueger, A. J., Arellano, S., Krotkov, N. A. and Yang, K.: Daily monitoring of Ecuadorian volcanic degassing from space, Journal of Volcanology and Geothermal Research, 176(1), 141-150, doi:10.1016/j.jvolgeores.2008.01.029, 2008.

Carn, S. A., and Prata F. J.: Satellite-based constraints on explosive $\mathrm{SO}_{2}$ release from Soufrière Hills Volcano, Montserrat, Geophys. Res. Lett., 37, L00E22, doi:10.1029/2010GL044971, 2010.

Carn, S. A., Krotkov, N. A., Yang, K., and Krueger, A. J.: Measuring global volcanic degassing 
with the Ozone Monitoring Instrument (OMI), Geological Society, London, Special Publications, 380, 229-257, doi: 10.1144/SP380.12, 2013.

Carn, S. A., L. Clarisse, and A. J. Prata. "Multi-decadal satellite measurements of global volcanic degassing." Journal of Volcanology and Geothermal Research 311 (2016): 99-134, 2016.

Castruccio, A., Clavero, J., Segura, A., Samaniego, P., Roche, O., Le Pennec, J.-L. and Droguett, B.: Eruptive parameters and dynamics of the April 2015 sub-Plinian eruptions of Calbuco volcano (southern Chile), Bulletin of Volcanology, 78(9), 62, doi:10.1007/s00445-016-1058-8, 2016.

Clarisse, L., Coheur, P. F., Chefdeville, S., Lacour, J. L., Hurtmans, D., \& Clerbaux, C.: Infrared satellite observations of hydrogen sulfide in the volcanic plume of the August 2008 Kasatochi eruption. Geophysical research letters, 38(10), 2011.

Clarisse, L., Coheur, P.-F., Theys, N., Hurtmans, D. and Clerbaux, C.: The 2011 Nabro eruption, a $\mathrm{SO}_{2}$ plume height analysis using IASI measurements, Atmospheric chemistry and physics, 14(6), 3095-3111, doi:10.5194/acp-14-3095-2014, 2014.

Danyushevsky, L.V., McNeill, A.W. and Sobolev, A.V.: Experimental and petrological studies of melt inclusions in phenocrysts from mantle-derived magmas: an overview of techniques, advantages and complications. Chemical Geology, 183(1), pp.5-24, 2002.

Devine, J. D., Sigurdsson, H., Davis, A. N. and Self, S.: Estimates of sulfur and chlorine yield to the atmosphere from volcanic eruptions and potential climatic effects, Journal of Geophysical Research: Solid Earth, 89(B7), 6309-6325, doi:10.1029/JB089iB07p06309, 1984. 
695

696

697

698

699

700

701

702

703

704

705

706

707

708

709

710

711

712

713

714

Eckhardt, S., Prata, A. J., Seibert, P., Stebel, K. and Stohl, A.: Estimation of the vertical profile of sulfur dioxide injection into the atmosphere by a volcanic eruption using satellite column measurements and inverse transport modeling, Atmospheric Chemistry and Physics, 8(14), 3881-3897, doi:doi:10.5194/acp-8-3881-2008, 2008.

Edmonds, M., Aiuppa, A., Humphreys, M., Moretti, R., Giudice, G., Martin, R. S., Herd, R. A., Christopher, T.: Excess volatiles supplied by mingling of mafic magma at an andesite arc volcano, Geochem. Geophys. Geosyst., 11, Q04005, doi:10.1029/2009GC002781, 2010.

Grainger, R. G., Mather, T. A., Pyle, D. M., Thomas, G. E., Smith, A. J. and Koukouli, M. E.: The vertical distribution of volcanic $\mathrm{SO}_{2}$ plumes measured by IASI, Atmospheric Chemistry and Physics, 16(7), 4343, doi:10.5194/acp-16-4343-2016, 2016.

Guo, S., Bluth, G. J., Rose, W. I., Watson, I. M. and Prata, A. J.: Re-evaluation of $\mathrm{SO}_{2}$ release of the 15 June 1991 Pinatubo eruption using ultraviolet and infrared satellite sensors, Geochemistry, Geophysics, Geosystems, 5(4), doi:10.1029/2003GC000654, 2004.

Hayer, C. S., Wadge, G., Edmonds, M. and Christopher, T.: Sensitivity of OMI $\mathrm{SO}_{2}$ measurements to variable eruptive behaviour at Soufrière Hills Volcano, Montserrat, Journal of Volcanology and Geothermal Research, $\quad 312, \quad 1-10$, doi:doi.org/10.1016/j.jvolgeores.2016.01.014, 2016.

Heng, Y., L. Hoffmann, S. Griessbach, T. Rößler, and O. Stein: Inverse transport modeling of volcanic sulfur dioxide emissions using large-scale simulations, Geosci. Model Dev., 9, 19271645, doi:10.5194/gmd-9-1627-2016, 2016.

715 Hughes, E. J., Sparling, L. C., Carn, S. A. and Krueger, A. J.: Using horizontal transport 
716 characteristics to infer an emission height time series of volcanic $\mathrm{SO}_{2}$, Journal of Geophysical

717 Research: Atmospheres, 117(D18), doi:10.1029/2012JD017957, 2012.

718

719

720

721

722

723

724

725

726

727

728

729

730

731

732

733

734

735

736

Ivy, D. J., Solomon, S., Kinnison, D., Mills, M. J., Schmidt, A. and Neely, R. R.: The influence of the Calbuco eruption on the 2015 Antarctic ozone hole in a fully coupled chemistry-climate model, Geophysical Research Letters, 44(5), 2556-2561, doi:10.1002/2016GL071925, 2017.

Krotkov, N. A., Schoeberl, M. R., Morris, G. A., Carn, S. and Yang, K.: Dispersion and lifetime of the $\mathrm{SO}_{2}$ cloud from the August 2008 Kasatochi eruption, Journal of Geophysical Research: Atmospheres, 115(D2), doi:10.1029/2010JD013984, 2010.

Krueger, A. J., Schnetzler, C. C. and Walter, L. S.: The December 1981 eruption of Nyamuragira volcano (Zaire), and the origin of the "mystery cloud" of early 1982, Journal of Geophysical Research: Atmospheres, 101(D10), 15191-15196, doi:10.1029/96JD00221, 1996.

Lopez-Escobar, L., Parada, M. A., Moreno, H., Frey, F. A. and Hickey-Vargas, R. L.: A contribution to the petrogenesis of Osomo and Calbuco volcanoes, Southern Andes $\left(41^{\circ} 00^{\prime}-41^{\circ}\right.$ 30'S): comparative study, Andean Geology, 19(2), 211-226, doi:http://dx.doi.org/10.5027/andgeoV19n2-a05, 1992.

Lopez, T., Carn, S., Werner, C., Fee, D., Kelly, P., Doukas, M., Pfeffer, M., Webley, P., Cahill, C. and Schneider, D.: Evaluation of Redoubt Volcano's sulfur dioxide emissions by the Ozone Monitoring Instrument, Journal of Volcanology and Geothermal Research, 259, 290-307, doi:10.1016/j.jvolgeores.2012.03.002, 2013.

Lowenstern, J. B.: Applications of silicate-melt inclusions to the study of magmatic volatiles. Magmas, fluids, and ore deposits, 23, 71-99, 1995. 
737 Marzano, F., Corradini, S., Mereu, L., Kylling, A., Montopoli, M., Cimini, D., Merucci, L.,

738 Stelitano, D.: Multisatellite Multisensor Observations of a Sub-Plinian Volcanic Eruption: The 7392015 Calbuco Explosive Event in Chile, IEEE Transactions on geoscience and remote sensing, 1 $740-16,2018$.

741 McCormick, B. T., Herzog, M., Yang, J., Edmonds, M., Mather, T. A., Carn, S. A., Hidalgo, S. 742 and Langmann, B.: A comparison of satellite-and ground-based measurements of $\mathrm{SO}_{2}$ emissions 743 from Tungurahua volcano, Ecuador, Journal of Geophysical Research: Atmospheres, 119(7), 744 4264-4285, doi:10.1002/2013JD019771, 2014.

745 Merucci, L., Burton, M., Corradini, S. and Salerno, G. G.: Reconstruction of $\mathrm{SO}_{2}$ flux emission 746 chronology from space-based measurements, Journal of Volcanology and Geothermal Research, 747 206(3), 80-87, doi:10.1016/j.jvolgeores.2011.07.002, 2011.

748 Métrich N., Wallace P. : Volatile abundances in basaltic magmas and their degassing paths 749 tracked by melt inclusions. In:Minerals, Inclusions \& Volcanic Processes, (eds K. Putirka\& F. 750 Tepley). Rev. Mineral. Geochem., 69, Chapter 10, pp. 363-402, 2008.

751 Morton, B. R., and J. S. Turner. "Turbulent gravitational convection from maintained and 752 instantaneous sources." Proc. R. Soc. Lond. A. Vol. 234. No. 1196. The Royal Society, 1956.

753 Moxnes, E. D., Kristiansen, N. I., Stohl, A,. Clarisse, L., Durant, A., Weber, K., Vogel, A.: 754 Separation of ash and sulfur dioxide during the 2011 Grímsvötn eruption, J. Geophys. Res. 755 Atmos., 119, 7477-7501, doi:10.1002/2013JD021129, 2014.

756 Nowlan, C. R., Liu, X., Chance, K., Cai, Z., Kurosu, T. P., Lee, C., Martin, R. V.: Retrievals of 757 sulfur dioxide from the Global Ozone Monitoring Experiment 2 (GOME-2) using an optimal 
estimation approach: Algorithm and initial validation, J. Geophys. Res., 116, D18301, doi:10.1029/2011JD015808, 2011.

Oppenheimer, C., Scaillet, B. and Martin, R. S.: Sulfur degassing from volcanoes: source conditions, surveillance, plume chemistry and earth system impacts, Reviews in Mineralogy and Geochemistry, 73(1), 363-421, doi:10.2138/rmg.2011.73.13, 2011.

Pardini, F., Burton, M., Vitturi, M. de'Michieli, Corradini, S., Salerno, G., Merucci, L. and Di Grazia, G.: Retrieval and intercomparison of volcanic $\mathrm{SO}_{2}$ injection height and eruption time from satellite maps and ground-based observations, Journal of Volcanology and Geothermal Research, 331, 79-91, doi:10.1016/j.jvolgeores.2016.12.008, 2017.

Platt U., Stutz J.: Differential Absorption Spectroscopy. In: Differential Optical Absorption Spectroscopy. Physics of Earth and Space Environments. Springer, Berlin, Heidelberg, 2008.

Rix, M., Valks, P., Hao, N., Erbertseder, T. and Van Geffen, J.: Monitoring of volcanic $\mathrm{SO}_{2}$ emissions using the GOME-2 satellite instrument, in Use of Remote Sensing Techniques for Monitoring Volcanoes and Seismogenic Areas, 2008. USEReST 2008. Second Workshop on, pp. 1-5, IEEE., 2008.

Rix, M., Valks, P., Hao, N., Loyola, D., Schlager, H., Huntrieser, H., Flemming, J., Koehler, U., Schumann, U. and Inness, A.: Volcanic $\mathrm{SO}_{2}$, $\mathrm{BrO}$ and plume height estimations using GOME-2 satellite measurements during the eruption of Eyjafjallajökull in May 2010, Journal of Geophysical Research: Atmospheres, 117(D20), doi:10.1029/2011JD016718, 2012.

Romero, J. E., Morgavi, D., Arzilli, F., Daga, R., Caselli, A., Reckziegel, F., Viramonte, J., DíazAlvarado, J., Polacci, M. and Burton, M.: Eruption dynamics of the 22-23 April 2015 Calbuco 
779 volcano (Southern Chile): Analyses of tephra fall deposits, Journal of Volcanology and 780 Geothermal Research, 317, 15-29, doi:10.1016/j.jvolgeores.2016.02.027, 2016.

SERNAGEOMIN, 2015a. Reporte Especial de Actividad Volcánica (REAV) Región de los Lagos. (REAV) Año 2015 Abril 22 (20:45 HL).

SERNAGEOMIN, 2015b. Reporte Especial de Actividad Volcánica (REAV) Región de los Lagos. Año 2015 Abril 22 (22:30 HL).

SERNAGEOMIN, 2015c. Reporte Especial de Actividad Volcánica (REAV) Región de los Lagos. Año 2015 Abril 23 (10:30 HL)

Sharma, K., Blake, S., Self, S., Krueger, A. J.: SO2 emissions from basaltic eruptions, and the excess sulfur issue, Geophys. Res. Lett., 31, L13612, doi:10.1029/2004GL019688, 2004.

Shinohara, H.: Excess degassing from volcanoes and its role on eruptive and intrusive activity, Reviews of Geophysics, 46(4), doi:10.1029/2007RG000244, 2008.

Sigmarsson, O., Haddadi, B., Carn, S.A., Moune, S., Gudnason, J., Yang, K., Clarisse, L., 2013. The sulfur budget of the 2011 grímsvötn eruption, Iceland. Geophys. Res. Lett. 40 (23), 60956100. http://dx.doi.org/10.1002/2013GL057760.

Solomon, S., Ivy, D.J., Kinnison, D., Mills, M.J., Neely, R.R. and Schmidt, A. Emergence of healing in the Antarctic ozone layer. Science, 353(6296), pp.269-274, 2016.

Sparks, R. S. J.: M. 1. Bursik, SN Carey, JS Gilbert, LS Glaze, H. Sigurdsson and AW Woods. Volcanic Plumes, Wiley: New York., 1997.

Stein, A. F., Draxler, R. R., Rolph, G. D., Stunder, B. J., Cohen, M. D. and Ngan, F.: NOAA's HYSPLIT atmospheric transport and dispersion modeling system, Bulletin of the American 
800

801

802

803

804

805

806

807

808

809

810

811

812

813

814

Meteorological Society, 96(12), 2059-2077, doi:10.1175/BAMS-D-14-00110.1, 2015.

Textor, C., Graf, H.-F., Timmreck, C. and Robock, A.: Emissions from volcanoes, in Emissions of Atmospheric Trace Compounds, pp. 269-303, Springer., 2004.

Theys, N., Campion, R., Clarisse, L., van Gent, J., Dils, B., Corradini, S., Merucci, L., Coheur, P. F., Van Roozendael, M. and Hurtmans, D.: Volcanic $\mathrm{SO}_{2}$ fluxes derived from satellite data: a survey using OMI, GOME-2, IASI and MODIS, Atmospheric Chemistry and Physics (ACP), doi:10.5194/acp-13-5945-2013, 2013.

Theys, N., De Smedt, I., Yu, H., Danckaert, T., van Gent, J., Hörmann, C., Wagner, T., Hedelt, P., Bauer, H., Romahn, F., Pedergnana, M., Loyola, D., and Van Roozendael, M.: Sulfur dioxide retrievals from TROPOMI onboard Sentinel-5 Precursor: algorithm theoretical basis, Atmos. Meas. Tech., 10, 119-153, https://doi.org/10.5194/amt-10-119-2017, 2017.

Van Eaton, A. R., Amigo, Á., Bertin, D., Mastin, L. G., Giacosa, R. E., González, J., Valderrama, O., Fontijn, K. and Behnke, S. A.: Volcanic lightning and plume behavior reveal evolving hazards during the April 2015 eruption of Calbuco volcano, Chile, Geophysical Research Letters, 43(7), 3563-3571, doi:10.1002/2016GL068076, 2016.

Vidal, L., Nesbitt, S. W., Salio, P., Farias, C., Nicora, M. G., Osores, M. S., Mereu, L. and Marzano, F. S.: C-band Dual-Polarization Radar Observations of a Massive Volcanic Eruption in South America, IEEE Journal of Selected Topics in Applied Earth Observations and Remote Sensing, 10(3), 960-974, doi:DOI: 10.1109/JSTARS.2016.2640227, 2017.

Wallace, P. J.: Volcanic $\mathrm{SO}_{2}$ emissions and the abundance and distribution of exsolved gas in magma bodies, Journal of Volcanology and Geothermal Research, 108(1), 85-106, 
821

822

823 $824 \quad 217-240,2005$.

825

826

827

828

829

830

831

832

833

834

835

836

837
doi:10.1016/S0377-0273(00)00279-1, 2001.

Wallace, P. J.: Volatiles in subduction zone magmas: concentrations and fluxes based on melt inclusion and volcanic gas data. Journal of Volcanology and Geothermal Research, 140(1-3),

Wallace, P.J. and Edmonds, M.: The sulfur budget in magmas: evidence from melt inclusions, submarine glasses, and volcanic gas emissions. Reviews in Mineralogy and Geochemistry, 73(1), pp.215-246, 2011.

Westrich, H. R. and Gerlach, T. M.: Magmatic gas source for the stratospheric $\mathrm{SO}_{2}$ cloud from the June 15, 1991, eruption of Mount Pinatubo, Geology, 20(10), 867-870, doi:10.1130/00917613(1992) 020<0867:MGSFTS>2.3., 1992.

Woods, A. W., and J. Kienle (1994), The dynamics and thermodynamics of volcanic clouds; theory and observations from the 15 and 21 April 1990 eruptions of Redoubt Volcano, Alaska, J. Volcanol. Geotherm. Res., 62, 273-299.

Yang, K., Liu, X., Bhartia, P. K., Krotkov, N. A., Carn, S. A., Hughes, E. J., Krueger, A. J., Spurr, R. J. D., Trahan, S. G.: Direct retrieval of sulfur dioxide amount and altitude from spaceborne hyperspectral UV measurements: Theory and application, J. Geophys. Res., 115, D00L09, doi:10.1029/2010JD013982, 2010. 